\title{
Ducatus, nebo Terra? (Na okraj 700. výročí vzniku Opavského vévodství)
}

\author{
Marek Starý
}

Právnická fakulta, Univerzita Karlova

Kontaktni e-mail: starym@prf.cuni.cz

\section{Ducatus or Terra?}

(To the 700th Anniversary of the Duchy of Opava)

\begin{abstract}
:
In the year 1318, the Duchy of Opava was created and became one of principalities, belonging to the Bohemian Crown as a fief. During the next two centuries, under the rule of the collateral branch of the Přemyslid dynasty, it was repeatedly divided between its male members. The aim of the study is to collect all the contemporary documents and references about these divisions and particularly to evaluate minutely the legal status of individual separated parts of the land. Especially the division in 1377 was crucial and originated three domains, to a large extent independent. However, while the territory of Krnov transformed into the principality sui iuris during the 15th century, the existence of the Duchy of Hlubčice was only fleeting.
\end{abstract}

\section{Keywords:}

Bohemian Crown; Duchy of Opava; succession; legal history; Přemyslid dynasty; co-ownership

\section{Klíčová slova:}

Česká koruna; Opavské vévodství; nástupnictví; právní dějiny; Přemyslovci; spoluvlastnictví

DOI: $10.14712 / 2464689 X .2019 .3$

Stoleté výročí vzniku samostatného československého státu na sklonku 1. světové války, jež se v loňském roce průběžně a dosti intenzivně slavilo, zastínilo celkem pochopitelně další, velmi kulaté, avšak z hlediska našich dějin přeci jen méně významné jubileum. Totiž vznik Opavského vévodství, které se jako specifický státoprávní útvar a zároveň pevná a stabilní součást českého státu konstituovalo v roce 1318. 
Počátky Opavského vévodství lze do určité míry spojovat již s vytvořením svébytné holasické provincie ve 12. století, stejně jako s poskytnutím některých zdejších statků jako apanáže nemanželskému (avšak ještě v dětském věku legitimovanému) synovi krále Přemysla Otakara II., knížeti Mikulášovi. ${ }^{1}$ Ten vystupoval s titulem dominus Opaviae poprvé již za života svého královského otce, v roce 1269.² Po svém návratu z uherského zajetí, do něhož upadl v nešt'astné bitvě na Moravském poli, pak dokázal ovládnout větší část Opavska a fakticky ho přetvořit ve svůj vladařský úděl. Ten ale nebyl jednoznačně státoprávně vymezen a byl do značné míry závislý na toleranci Mikulášova mladšího polorodého bratra, krále Václava II. Ten posléze Opavsko od Mikuláše převzal a náhradou mu poskytl hejtmanský úřad ve Velkopolsku. Po olomoucké královraždě v roce 1306 se Mikuláš na Opavsko vrátil a pokusil se zde restituovat svoji vládu. V chaotických poměrech se ale nedokázal prosadit a ze země byl záhy opět vypuzen. ${ }^{3}$

Byl to tak teprve Mikulášův stejnojmenný syn, který získal v roce 1318 Opavsko jako jednoznačně konstituované knížectví - zřejmě jako odměnu za to, že se přidržel krále Jana Lucemburského v jeho předchozím konfliktu se šlechtou. Bohužel, nedochovala se Janova listina, jíž došlo k udělení léna, ${ }^{4}$ naproti tomu je ale možno seznámit se s originálem reciproční listiny, tedy lenního slibu, který byl složen 3. července 1318 v Praze. Podle něj mělo Opavsko charakter feuda, dědičného v mužské linii Mikulášových potomků. ${ }^{5} \mathrm{~V}$ roce 1348 bylo Opavsko společně s Moravským markrabstvím a Olomouckým biskupstvím prohlášeno za součást České koruny. ${ }^{6}$ Tím byl na jedné straně znovu zdůrazněn ,,moravský původ“ Opavského vévodství, na stranu druhou ale i jeho neodvislost na markrabatech z moravské lucemburské sekundogenitury. Z tohoto pohledu je těžké jednoznačně popsat, jaké bylo vlastně v pozdním středověku a raném novověku postavení Opavska - i když ho

1 Srovnej především BAKALA, J. Holasická provincie a formování opavského vévodství. Časopis Slezského muzea, série B, 1969, 1/XVIII, s. 9-23; TÝŽ. Geneze opavského Slezska a římská Kurie. In: BARCIAK, A. (red.). Lux Romana w Europie Środkowej ze szczególnym uwzględnieniem Śląska. Katowice: Instytut Górnośląski, 2001, s. 55-64; KOUŘIL, P. - PRIX, D. - WIHODA, M. Hrady českého Slezska. Brno Opava: Archeologický ústav AV ČR, 2000, zejm. s. 404-437.

2 ŠEBÁNEK, J. - DUŠKOVÁ, S. (eds.). Codex diplomaticus et epistolaris regni Bohemiae, Tomi V Fasciculus 2. Pragae: Academia, 1981, s. 180-181, č. 590.

3 K osobnosti Mikuláše I. naposledy přehledně WIHODA, M. Mikuláš I. Opavský mezi Přemyslovci a Habsburky. Český časopis historický, 2001, 2/IC, s. 209-230.

$4 \quad$ Udělení léna zmínil Petr Žitavský ve Zbraslavské kronice (Eodem anno Johannes, rex Boemie, ducatum Oppauie contulit Nycolao eleganti iuveni circiter triginta annos etatis habenti, filio videlicet senioris ducis Nycolai), stejně jako následně i Přibík Pulkava z Radenína. EMLER, J. (ed.). Fontes rerum Bohemicarum (= FRB), Tom. IV. Praha: Nákladem Nadání Františka Palackého, 1884, s. 250; Tom V. Praha: Nákladem Nadání Františka Palackého, 1893, s. 200-201.

5 Národní archiv (=NA) Praha, fond Archiv České koruny (=AČK), č. 79; pozdější opis této latinské listiny (z počátku 17. století) je též v NA Praha, fond České gubernium - Guberniální listiny (ČG-L), i.č. 27, sign. L II 20. Edičně je listina zpř́ístupněna např. v Regesta diplomatica nec non epistolaria Bohemiae et Moraviae. Pars III. EMLER, J. (ed.). Pragae: Regiae scientiarum societatis Bohemiae, 1890, s. 186-187, č. 454. Její text zahrnul do svého letopisu též Přibík Pulkava z Radenína. FRB V., s. 321-322.

6 AČK, č. 301; edice CHLUMECKY, P. (ed.). Codex diplomaticus et epistolaris Moraviae (= CDM), VII. Band. Brünn: Verlag des Mährischen Landes-Ausschusses, 1858, s. 564-567, č. 775; HRUBÝ, V. (ed.). Archivum coronarum regni Bohemiae. Tomus II. Pragae: Sumptibus Ministerii Scholarum et Instructionis Publicae, 1928, s. 59-62, č. 60. K obsahu listiny podrobněji např. BOBKOVÁ, L. 7. 4. 1348. Ustaveni Koruny království českého. Český stát Karla IV. Praha: Havran, 2006, s. 61-65. 
tak literatura neuvádí, bylo by asi nejpřiléhavější považovat ho za jednu ze zemí, tvořících korpus České koruny, a stavět ho tedy na roveň Moravy i Slezska. ${ }^{7}$

$\mathrm{Na}$ okraj je možno připomenout, že i v dalších desetiletích bylo postavení vévodství předmětem nejasností a sporů. Díky postupné integraci přemyslovských panovníků (i jejich nástupců z jiných dynastií) mezi slezská knížata se i Opavsko sbližovalo se sousedním Slezskem, na druhou stranu ale šlechta, resp. stavy inklinovaly nadále k Moravě, aniž by ovšem mohla být řeč o tom, že by Opavsko bylo de iure součástí markrabství. ${ }^{8}$ Vše vyvrcholilo v 16. století, kdy se státoprávní př́islušnost Opavska stala předmětem vleklého právního sporu, ${ }^{9}$ který vyeskaloval udělením Opavska lénem Karlovi z Lichtenštejna ze strany císaře Matyáše listinou vydanou dne 4. ledna 1614 z titulu nejvyššího knížete ve Slezsku. Habsburský panovník v ní Opavsko prohlásil za součást Slezska, Karlovi povolil psát se „Herzog zu Troppau in Schlesien“ a obdařil ho stejnými právy, jaká mají ostatní slezská knížata. ${ }^{10}$

Mikuláš II., jenž se stal v roce 1318 prvním vládcem jasně státoprávně konstituovaného Opavského vévodství, zanechal čtyřri syny, kteří se dožili dospělosti. Dva z nich sice posléze zemřeli bezdětní, i tak ale došlo v dalších generacích k rozvětvení rodu do několika linií. ${ }^{11}$ Podobně jako u jiných aristokratických rodin, i u Přemyslovců byla ovšem genealo-

7 K podobnému závěru dospěl nedávno také KOZÁK, P. (ed.). Červená kniha Opavského knižectví. Edice registra komunikace opavských stavi̊ z let 1614-1618 ve véci jejich sporu s Karlem z Lichtenštejna. Opava: Zemský archiv, 2015, s. 11-14. Ze starší literatury ke státoprávním poměrům Opavska ve středověku a raném novověku srovnej zejména KAPRAS, J. O státoprávních poměrech Opavska. Věstník Matice opavské, 1908, 16, s. 35-49, 1909, 17, s. 17-54; BULÍN, H. K otázce právního poměru Opavska k Moravě ve 14. století. Slezský sborník, 1957, 1/LV, s. 73-79; FUKALA, R. Státoprávní, správní a územní vývoj Opavska do počátku 16. století. Husitský Tábor, 2002, 13, s. 203-226; KONVIČNÁ, J. Opavsko - Morava, nebo Slezsko? (Několik poznámek k politicko-správnímu vývoji Opavska do konce husitských válek). In: BOBKOVÁ, L. (ed.). Korunni země v dějinách českého státu I. Integrační a partikulární rysy českého státu v pozdním středověku. Ústí nad Labem: Pro ústav českých dějin FF UK Praha nakl. Albis International, 2003, s. 59-76.

8 Upozornit lze v této souvislosti na moravský landfrýd, uzavřený v roce 1421 - jeho členem byl i vévoda Přemysl Opavský a Opava byla společně s Brnem, Olomoucí a Znojmem jedním ze čtyř center, v nichž se měli obyvatelé Moravy odřeknout bludů. Archiv český čili staré pisemné památky české i moravské (= AČ), dil X. Praha: Domestikální fond království Českého : Bursík \& Kohout, 1890, s. 246-250, č. 5.

9 O něm podrobněji FUKALA, R. Státoprávní spor o Opavsko v letech 1529-1606. Sbornik praci historických. Sv. 17. Acta Universitatis Palackianae Olomucensis. Facultas philosophica. Historica, 2000, 29, s. 69-82. Prakticky doslovně totožný text byl znovu publikován i v JIRÁSEK, Z. a kol. Slezsko v dějinách českého státu II. 1490-1763. Praha: Nakladatelství Lidové noviny, 2012, s. 59-67.

10 Listinu publikoval již BRAUN, W. (ed.). Die Urkunde über die Verleihung des Fürstentums Troppau an Fürst Karl von Liechtenstein im Jahre 1614. Zeitschrift für Geschichte und Kulturgeschichte Österreichisch-Schlesiens, 1914, IX, s. 73-77, nově ji zpřístupnil též KOZÁK, P. (ed.). Červená kniha Opavského knižectví, s. 219-223. K některým sporným otázkám týkajícím se jejího vydání blíže BRŇOVJÁK, J. Lichtenštejnové a jejich knížecí tituly v 17.-18. století (1. část). Genealogické a heraldické listy, 2017, 3/XXXVII, s. 14-17.

11 Genealogie opavských Přemyslovců dosud postrádá moderní kritické zpracování. Základní přehled se pokusili sestavit např. CHOCHOLATÝ, F. Genealogie opavských Přemyslovců 1255-1525. Listy Genealogické a heraldické společnosti v Praze. Acta genealogica ac heraldica, 6. řada, záŕí 1978, s. 129-153, či WEGENER, W. Die Herzöge von Troppau und Leobschütz, Jägerndorf und Ratibor, des Stammes der Přmysliden 1278-1521. Göttingen: Reise-Verl., 1964. 
gická expanze vystřídána degresí fertility a v roce 1521 vymřeli osobou knížete Valentina Ratibořského, reprezentujícího pátou generaci potomků Mikuláše II. ${ }^{12}$

Zprvu stoupající množství mužských př́slušníků dynastie nemělo ale rozměr čistě genealogický, ale promítalo se velmi zásadně i do roviny majetkoprávní, ba dokonce státoprávní. Větší množství potomků bylo sice na jednu stranu zárukou dalšího zachování rodové kontinuity, na stranu druhou ale otevíralo palčivou otázku jejich dostatečného ekonomického zabezpečení a mocenské seberealizace. Řešením mohlo být předurčení „přebytečných“" synů církevní dráze, ale i tato možnost narážela na objektivní limity. ${ }^{13}$ Lákavým vzorem pro mladší sourozence se pak stávaly poměry v okolních knížectvích slezských, v nichž platilo, že rovnocenné právo na vládu si mohli po smrti vladaře nárokovat všichni jeho synové bez ohledu na stáŕí. V případě Přemyslovců problém poněkud oddálil zisk sousedního hornoslezského Ratibořského vévodství, jež bylo Mikulášovi II. uděleno lénem v letech 1337 a znovu 1339, ${ }^{14}$ avšak zejména v 15. století již ani toto významné rozšíření rodové mocenské základny nemohlo zabránit opakovanému drobení a postupnému „okrajování“ rodového majetku a pauperizaci jednotlivých členů první české panovnické dynastie.

Nutno podotknout, že obdobnému problému jako opavští Přemyslovci a slezští Piastovci čelili v pozdním středověku mnohé aristokratické rodiny. Řešení, poněkud ovšem macešské vůči mladším potomkům, přinesl právě fideikomis, ${ }^{15}$ respektive uspořádání jemu obdobná - zde je nutno vzpomenout především na rodové vladařství, které bylo ve druhé polovině 15. století zavedeno u jihočeských velmožů erbu růže, Rožmberků. ${ }^{16}$ Bez institucionálního právního zakotvení nedílnosti rodového majetku nebylo možné jeho drolení

12 K demografickým trendům v aristokratických rodinách raného novověku srovnej především HONC, J. Populační vývoj šesti generací 125 českých panských rodů v letech 1502-1794. Historická demografie, 1969, 3, s. 20-51. Valentinovi Ratibořskému věnoval biografický medailon MIKA, N. Ostatní Przemyślida - książę Walentyn Garbaty. In: CIESIELSKI, T. - IWAŃCZAK, W. (ed.). Czechy i Polska między Wschodem i Zachodem - średniowiecze $i$ wczesna epoka nowożytna (materialy międzynarodowej konferencji naukowej). Warszawa: Wydawnictwo DiG, 2016, s. 51-65.

13 Z opavských Přemyslovců byl původně k církevní dráze předurčen Mikuláš V. († po 1435), který se jí ale nakonec vyhnul. Jeho mladší bratr Přemysl II. (†1478) se stal vratislavským kanovníkem, několik kanonikátů získal i jejich synovec Přemysl III. (†1493), poslední př́slušník opavské sekundogenitury.

14 Národní knihovna Praha, Rukopisy, sign. XVI C 7, Registrum St. Wenceslai (= RSW), fol. 36r-38r, č. 23, fol. 43r-45r, č. 26, fol. 67v-69r, č. 34; WATTENBACH, W. - GRÜNHAGEN, C. (eds.). Codex diplomaticus Silesiae (= CDS), VI. Band. Registrum St. Wenceslai. Breslau: J. Max \& Komp., 1865, s. 182-186, č. IV a V; GRÜNHAGEN, C. - MARKGRAF, H. (eds.). Lehns- und Besitzurkunden Schlesiens und seiner einzelnen Fürstenthümer im Mittelalter (= LBS), II. Theil. Leipzig: S. Hirzel, 1883, s. 380-383, č. 2, s. $385-386$, č. 4.

15 K fideikomisu v českém právu srovnej především PINSKER, Č. České zřízení rodové. Kapitola z práva svěřenského. Právnické rozhledy, 1907, příloha ročníku VIII, a URFUS, V. Rodinný fideikomis v Čechách. Právnéhistorické studie, 1962, 9, s. 193-237.

16 Autorem myšlenky a právní konstrukce vladařství se stal po husitských válkách Oldřich (II.) z Rožmberka, který k jeho zakotvení využil listinné falzum, hlásící se do doby vlády Karla IV. (1360). Jeho text byl vydán v RYNEŠOVÁ, B. (ed.). Listář a listinář Oldřicha z Rožmberka. Svazek I. 1418-1437. Praha: Nákladem Ministerstva školství a národní osvěty, 1929, s. 245-251, č. 360. Ve své velmi cenné studii upozornil MARÁZ, K. K problematice padělání pečetí na sklonku středověku. Sfragistický příspěvek k falzům Oldřicha II. z Rožmberka. Sborník archivnich prací, 1998, 1/XLVIII, s. 62-64, 73-78, že padělána je nejen listina, ale i přivěšená (oboustranná) pečet' císaře Karla a stejně tak i další čtyři přivěšené pečeti bratři Jošta, Petra, Jana a Oldřicha z Rožmberka. 
efektivně zabránit. ${ }^{17}$ I z historie Opavska jsou sice známy př́klady, kdy sourozenci spravovali osudy země společně, avšak dělení vlády, respektive i její mocenské základny, se prosazovalo jako obvyklejší a dost možná i efektivnější řešení podobných situací.

Z dějin Opavska je známo přinejmenším šest případů, kdy byla vláda mezi jednotlivé príslušníky přemyslovské dynastie rozdělena. Nejdůležitější pro budoucí vývoj bylo patrně hned to první, k němuž došlo v roce 1377. Schylovalo se k němu vlastně již deset let, nebot' již 28. února 1367 vydal císař Karel IV. společně s břežským a těšínským vévodou výrok, jímž se vyjádřil k stížnostem druhorozeného Mikulášova syna Mikuláše III. a stanovil, že má dostávat čtvrtinu př́ijmů z vévodství, ale také splácet čtvrtinu otcových dluhů. Kromě toho mu měla být do čtyř let vyplacena částka 2500 grošů jako věno jeho matky Hedviky Olešnické. Konečně císař připustil vzájemný dědický nápad v prŕípadě smrti některého $\mathrm{z}$ bratrů. ${ }^{18} \mathrm{~V}$ roce 1372 pak došlo k reálnému vymezení Mikulášova čtvrtinového podílu v samotném městě Opavě. ${ }^{19}$

K rozdělení celého vévodství došlo nicméně až poté, co dospěl i Václav, třetí ze čtyř synů Mikuláše II. Šlo přitom vlastně o dvě dělení bezprostředně na sebe navazující. Osmičlenná šlechtická komise v čele se zemským komorníkem Mikulášem z Malenovic nejprve vydala 18. dubna 1377 dílčí listy, jimiž bylo vévodství rozděleno na dvě poloviny. Z nich západní, krnovská, byla vylosována pro starší bratry Jana I. a Mikuláše III., východní opavská připadla mladším Václavovi a Přemyslovi. ${ }^{20}$ Jan s Mikulášem, kteří pocházeli $\mathrm{z}$ různých matek, ale sáhli vzápětí $\mathrm{k}$ další dělbě. Částečně obměněná, opět osmičlenná

17 Nepostačující byl v tomto směru institut nedílu, nebot' ten již v pohusitské době ztratil svou někdejší stabilitu a stalo se celkem běžné, že dříve či později docházelo k jeho likvidaci a rozdělení rodinného majetku mezi jeho jednotlivé členy. K nedílu v českém právu existuje jen několik prací staršího data, z nichž zejména zasluhují zmínku KADLEC, K. Rodinný nedíl čili zádruha v právu slovanském. Praha: vl. nákl., 1898, a RAUSCHER, R. O rodinném nedilu v českém a uherském právu zemském pred Tripartitem (Zvláštní otisk z časopisu Učené Společnosti Šafaříkovy, 2). Bratislava: nákladem vlastním, 1928. Odkazy na další práce obsahuje studie HORSKÝ, J. Ältere Diskussion über die Zadruga und die Familienbesitzgemeinschaft in Böhmen und das heutige Studium der Familienstrukturen und Typen. Historická demografie, 1993, 17, s. 37-51, a encyklopedické heslo STARÝ, M. Nedíl. In: SCHELLE, K. - TAUCHEN, J. (eds.). Encyklopedie českých právních dějin. IV. svazek N-O. Plzeň: Aleš Čeněk, 2016, s. 199-206.

18 Text listiny se dochoval v kopiáři olešnických knížat ze 14. století a v poněkud mladším RSW, fol. 69r-70v, č. 35 a fol. $615 \mathrm{v}$, č. 516. Podle prvého zdroje byl in extenzo vydán v LBS II, s. 479-481, č. 19; stručným regestem ho zmínil ŻERELIK, R. Najstarszy kopiarz ksiązat olešnických i kozielsko-bytomskich. Historia CLXXXV. Wrocław: Wydawnictwo Uniwersytetu Wrocławskiego, 2012, s. 174, č. 189. Podle opolského registra byl zpracován regest v CDS VI., s. 9, č. 39. Z jednoho z těchto zdrojů je nepochybně převzat text, který publikoval SOMMERSBERG, F. W. Silesiacarum rerum scriptores. Lipsiae: Hubert, 1829, s. 842-843, a z něhož vychází stručný obsah v Regesten zur Geschichte des Herzogthums Troppau (= RGHT). KOPETZKY, F. (ed.). Wien: In Commission b. C. Gerold‘s Sohn, 1871, s. 93-94, č. 347.

19 Vyplývá to z výpisků Josefa Zukala z nedochované opavské kroniky, známé podle místa někdejšího uložení jako Chronicon Fürstenstein. Zemský archiv (= ZA) Opava, fond Pozůstalost Josefa Zukala, i.č. 208a, Chronik Fürstenstein (= CHF), fol. 11r. Obsah zápisu reprodukoval PRIX, D. Vévoda Václav I. Opavský. Příspěvek k dějinám Opavského vévodství počátkem poslední čtvrtiny 14. století. Acta historica et museologica Universitatis Silesianae Opaviensis, 1997, 3, s. 62.

20 Německy psané, v originále nedochované dílčí listy byly podle RSW, fol. $2 \mathrm{v}-4 \mathrm{v}$, č. 3, fol. $571 \mathrm{v}-573 \mathrm{r}$, č. 473, fol. 610v-612r, č. 510, poprvé vydány v CDS VI., s. 195-197, č. XIV (list na opavskou část) a s. 197-200, č. XV (list na krnovskou část). Nedlouho nato byly znovu otištěny v LBS II, s. 484-489, č. 23. Český překlad obou listů i s následujícím dokumentem a s podrobnějším komentářem publikoval o něco později PRASEK, V. Překlad s výkladem na dílčí listy země Opavské z r. 1377. In: VII. program českého vyššiho gymnasia v Opavě za rok 1889/1890. Opava, 1890, s. 3-24 (text a překlad listů je 
komise znovu zasedla a výsledkem jejího jednání se stala nová listina z 21. dubna, jež popisovala díl Mikulášův. ${ }^{21}$ Opavsko tak bylo rozděleno prakticky na tři části - Krnovsko, k němuž patřily hrady Fürstenwalde a Cvilín a města Krnov a Bruntál, Hlubčicko s hradem Edelštejnem, městy Cukmantl, Hlubčice a Nová Cerekev a konečně samotné okleštěné Opavsko, jehož součástí byly hrady Hradec nad Moravicí a Landek a města Opava a Hlučín. ${ }^{22}$ I když uvedené uspořádání nemělo trvalý charakter, předznamenalo přeci jen budoucí vývoj, v němž se kromě Opavy stala centry samostatných knížecích údělů další dvě bohatá a strategicky položená města, Krnov a Hlubčice.

Roztříštěnost Opavska, nad nímž visela do budoucna jako Damoklův meč hrozba brzkého rozdělení druhé, opavské poloviny, byla do značné míry překonána v důsledku dalšího vývoje dynastické genealogie. Již v roce 1381 zemřel mladý kníže Václav, ${ }^{23}$ čímž nebezpečí dalšího štěpení odpadlo, a když v roce 1394 zesnul bezdětný Mikuláš III., převzal po něm hlubčickou doménu na základě předchozích dohod rovněž nejmladší Přemysl. ${ }^{24}$ Ten tedy opět spojil ve svých rukou tři čtvrtiny země.

Svébytné byly pouze osudy Krnovska, které v roce 1377 připadlo Janovi. Ten se po smrti Mikuláše II. ujal vlády v Ratibořsku, a to z toho důvodu, že byl jediným synem z Mikulášova prvního manželství s ratibořskou kněžnou Annou. Ratibořsko sice udělil Jan Lucemburský v letech 1337 a 1339 lénem Mikulášovi a o svůj dědický nárok se tak mohli na první pohled ucházet všichni synové, podle všeho ale o výhradních nárocích Janových panoval všeobecný konsenzus. S nemalou pravděpodobností lze uvažovat o tom, že omezení dědického práva na sestřino potomstvo ustanovil Mikulášův švagr, ratibořský kníže Lešek (†1336), o jehož poslední vůli (v písemné podobě ovšem nedochovanou) se pretense Mikuláše II. opíraly. ${ }^{25}$ Každopádně, Ratibořsko se po smrti Mikuláše II. stalo mocenskou základnou přemyslovské primogenitury a krnovská část Opavska zůstávala v jejím stínu. Janův syn Jan II. se pak nikterak nerozpakoval řešit své finanční problémy tím, že celý svůj podíl rodné země prodal v roce 1384 knížeti Vladislavovi Opolskému. ${ }^{26}$ Od něho

na s. 10-17). Stručně, ale přehledně k dělení Opavska v roce 1377 dále např. KOUŘIL - PRIX - WIHODA, Hrady českého Slezska, s. 476-477.

21 RSW, fol. 4v-6r, č. 4; CDS VI., s. 200-201, č. XVI; LBS II., s. 490-491, č. 24.

22 Toto popsání dílů je pouze velmi rámcové, omezuje se na zeměpanské hrady a města a abstrahuje od menších majetkových hodnot (vsí, dvorů atd.), jakož i svrchovanosti nad statky šlechtickými, což vše bylo př́íslušnými listinami dopodrobna rozvedeno.

23 Jeho nadmíru zdařilou biografii publikoval PRIX, Vévoda Václav I. Opavský, s. 54-89.

24 Dohoda mezi Mikulášem III. a Přemyslem se v písemné podobě nedochovala, je ale jasně doložitelná listinou ze 4. dubna 1385, v níž olešnická knížata slíbila předat Přemyslovi po Mikulášově smrti veškeré jím zastavené majetky (jmenovitě jsou uvedeny Hlubčice, Edelštejn, Cukmantl, Landek, Hlučín, Cvilín, Křenovice a Dívčí hrad). RSW, fol. 7r-8r, č. 6, regest je v CDS VI., s. 15, č. 70. Celý text dohody otiskl KAPRAS, O státoprávních poměrech Opavska (2. část), s. 26, pozn. 10.

25 O knížectví musel ovšem Mikuláš svést tuhý boj s Leškovými piastovskými př́ibuznými. Stručně s odkazy na starší literaturu BAKALA, J. Problematická integrace Opavska s Ratibořskem ve světle listin Jana Lucemburského. In: Sto let od narozeni profesora Jindřicha Šebánka. Sborník přispěvků. Brno: Moravský zemský archiv v Brně, 2000, s. 69-77, MIKA, N. Przejęcie księstwa raciborskiego przez wladcę opawskiego Mikołaja II. In: Opava. Sborník k dějinám města 2. Opava: AVE, 2000, s. 11-13.

26 K dataci transakce KOUŘIL - PRIX - WIHODA, Hrady českého Slezska, s. 510. Obvykle se v literatuře klade spíše až do roku 1385 - tak např. ŠTĚPÁN, V. Moravský markrabě Jošt (1354-1411). Brno: Matice moravská, 2002, uvažoval o lednu 1385. Stejně tak se v literatuře často tvrdí, že Krnovsko nebylo prodáno, nýbrž pouze dáno do zástavy. Avšak v tomto směru nepřipouští pochybnosti listina Václava IV. z 23. března 1385, jíž římský a český král jakožto lenní pán ex post prodej schválil. Regest listiny, jejíž text se dochoval 
získal v roce 1390 větší část této državy moravský markrabě Jošt Lucemburský, s Přemyslovci blízce spř́zzěný, zatímco Janovi se podařilo vykoupit zpět alespoň její menší část s hradem Fürstenwalde a městem Bruntálem. ${ }^{27}$ Zbytek Krnovska pak přeci jen získal v roce 1422, když ho vykoupil od knížete Ludvíka Břežského, do jehož rukou se mezitím dostalo. ${ }^{28}$ Právě toto období vytržení z přemyslovských rukou ale vedlo k znatelnému oslabení pout mezi Krnovskem a zbytkem Opavska. A nic na tom nemohla změnit ani listina Václava IV. z 16. srpna 1404, jíž uznal Opavsko za společné léno všech přemyslovských knížat a zaručil vzájemný dědický nápad jednotlivých př́slušníků rodu. ${ }^{29}$

Právě v době, kdy se Krnovsko nacházelo pod vládou Joštovou, proběhlo mezi opavskými Přemyslovci další dělení rodového majetku, tentokrát ovšem zcela marginální. Přistoupili k němu bratři Jan II. a Mikuláš IV. ${ }^{30}$ Mechanizmus rozdílu se nijak významně nelišil od předchozího př́padu: oba bratři jmenovali komisi, složenou v tomto př́ipadě z jednoho šlechtice, jednoho duchovního, členů bruntálské městské rady a městského fojta. Ti pak vystavili 1. ř́jjna 1405 listinu, v níž byly podrobně popsány díly obou bratří, stejně jako majetek, který jim zůstal i po rozdělení společný. ${ }^{31}$ Za marginální lze toto dělení považovat ze dvou důvodů - za prvé bylo jeho předmětem pouze nevelké území, tvořící toliko malou část Opavska v celém jeho původním rozsahu, jednak mělo toto uspořádání jepičí život, nebot' Mikuláš vzápětí zemřel. ${ }^{32}$

Mnohem zásadnější pro další osudy Opavska bylo třetí dělení, jehož aktéry se stali synové vévody Přemysla I. ${ }^{33}$ Tento obratný diplomat vládnoucí ve třech čtvrtinách Opav-

v RSW, fol. 323v-324r, č. 271, je v CDS VI., s. 15, č. 69, velmi stručně ji zmiňují též LBS II., s. 493, č. 27. Její text publikoval KAPRAS, O státoprávních poměrech Opavska (2. část), s. 43-44.

27 Kupní smlouva mezi Vladislavem Opolským a Joštem Lucemburským je uložena v AČK, č. 1286, její edice byla otištěna v LBS II., s. 494-495, č. 29. Kupní cena činila 11200 hřiven grošů. Listina o prodeji Bruntálska se nedochovala, z výpovědi vévody Vladislava Opolského, učiněné 10. dubna 1397, je ale patrné, že Jan část původní rodové domény Přemyslovců získal za 10950 hřiven grošů. Tamtéž, s. 495-496, č. 30.

28 Edice souvisejících dokumentů jsou v LBS II., s. 500-502, č. 36 (prodej Krnovska Zikmundem Ludvíkovi, 23. dubna 1421), s. 502-503, č. 37 (Zikmundův lenní list na Krnovsko pro Jana, 15. března 1422) a s. 503, č. 38 (Ludvíkova kvitance Janovi na úplné zaplacení Krnovska, 16. října 1422).

29 Text nedochované listiny otiskl SOMMERSBERG, Silesiacarum rerum scriptores, Tomus I, s. 845; a s odkazem na něj se objevil i v LBS II, s. 496-497, č. 31.

$30 \quad$ V rodokmenech opavských Přemyslovců vystupuje tento Mikuláš někdy bez číslovky a jako Mikuláš IV. je označován druhorozený syn knížete Přemysla Opavského. Avšak toto číslování se nijak neopírá o dobovou titulaturu a v zásadě není důvod, proč Mikuláše, který se dožil dospělosti, stal se aktérem několika významných právních aktů, a dokonce obdržel vlastní vladařský úděl, z číslované řady jeho jmenovců vynechat. Jako Mikuláše IV. označili mladšího syna Jana I. např. WEGENER, Die Herzöge von Troppau und Leobschütz, Jägerndorf und Ratibor, Tafel 2 (nepřidělil ale naopak řadovou číslovku jeho opavskému bratranci) či SCHWENNICKE, D. Europäische Stammtafeln. Stammtafeln zur Geschichte der Europäischen Staaten. Neue Folge. Band III. Teilband 1. Herzogs.- und Grafenhäuser des heiligen römischen Reiches. Andere europäische Fürstenhäuser. Marburg: J. A. Stargardt, 1984, Tafel 18 (jehož číslování se jeví nejkonzistentnější).

31 CDS II. WATTENBACH, W. (ed.). Urkunden der Klöster Rauden und Himmelwitz, der Dominicaner und Dominicanerinnen in der Stadt Ratibor. Breslau: Max, 1859, s. 48-50, č. 49. Viz též s některými nepřesnostmi THANNABAUER, J. Die Freudenthaler Teilungsurkunde vom 1. Oktober 1405. Freudenthaler Ländchen, 1925, 5, s. 1-6, 9-12.

32 Dozajista byl mrtev 30. listopadu 1407, kdy Jan II. uzavřel dědickou smlouvu se strýcem Přemyslem a jeho syny. LBS II, s. 390-394, č. 11 a 12.

33 K jeho osobě minuciózně ČAPSKÝ, M. Vévoda Přemek Opavský (1366-1433). Ve službách posledních Lucemburků. Brno - Opava: Matice moravská, 2005. 
ska patřil nepochybně k nejschopnějším jedincům, které opavská přemyslovská dynastie dějinám nabídla. Měl ale tu smůlu, že závěrečná léta jeho vlády se překrývala s husitskou revolucí, která dosti výrazně zasáhla i do osudů samotného Opavska a především katastrofálním způsobem zdecimovala knížecí finance. Když sepisoval Přemysl krátce před smrtí, 18. záŕí 1433 svůj testament, projevil přání, aby jeho synové přinejmenším po dobu, po kterou potrvá ohrožení ze strany podobojích, ,zemi netrhali“ a aby se všichni podřídili autoritě nejstaršího Václava II. ${ }^{34}$ Výslovně pak zapověděl, aby se jakéhokoliv reálného podílu dostalo jeho druhorozenému Mikulášovi V., který pohrdl slibnou duchovní kariérou a již za otcova života se neslavně vyznamenal naděláním dluhů. ${ }^{35}$ Avšak již 2 . února 1434 provedla dvanáctičlenná šlechtická komise v rozporu s tímto přáním rozdíl, přičemž dochovaná dílčí listina popisuje pouze čtvrtinu, která připadla - v rozporu s otcovým přáním - právě nepokojnému Mikulášovi, který byl patrně iniciátorem dělení. ${ }^{36}$ Jejím sídlem byl hrad Edelštejn a patřila k ní města Cukmantl a Hlubčice. Je poněkud kuriózní, že Mikuláš zrrejmě ještě v tomtéž roce prodal tento svůj úděl staršímu Václavovi. ${ }^{37} \mathrm{~V}$ literatuře se soudí, že mladší bratři Vilém a Arnošt obdrželi své díly teprve vzápětí, zřejmě na podzim roku 1434. ${ }^{38}$ Avšak v zásadě nic neodporuje hypotéze, že ve skutečnosti bylo celé rozdělení realizováno právě již 2. února, čemuž ostatně nasvědčují i některé formulace dochovaného dílčího listu. ${ }^{39}$ Listiny vymezující podíly ostatních bratří kromě Mikuláše nejsou dochovány, je ale zjevné, že samo město Opava bylo rozděleno na čtyři díly, přičemž každá část měla svou vlastní městskou radu. ${ }^{40}$

34 Jeho zdařilou biografii sestavil opět PRIX, D. Vévoda Václav II. Opavský a Hlubčický. Ve stínu otce, husitů a bezvládí. Časopis Slezského zemského muzea, 1999, 2/XLVIII, s. 152-192 (1. část), 1999, 3/XLVIII, s. $193-223$ (2. část).

35 Testament, přepsaný do RSW, fol. 50r-52r, č. 30 a fol. 78v-80r, č. 45, otiskl s komentářem KAPRAS, J. Testament knížete Přemka a jeho provedení. Věstník Matice opavské, 1907, 15, s. 1-7.

36 RSW, fol. 602r-605v, č. 506; obsáhlý regest je v CDS VI., s. 55-57, č. 188. Celý text otiskl též KAPRAS, Testament knížete Přemka a jeho provedení, s. 4-7.

37 Bližší okolnosti nejsou známy, již v září 1434 ale Václav uplatňoval svou svrchovanost nad Hlubčicemi. RGHT, s. 138, č. 485.

38 KOPETZKY, F. Zur Geschichte und Genealogie der Přemyslidischen Herzoge von Troppau. Archiv für österreichische Geschichte, 1869, Band XLI, s. 52, soudil, že k dělení mezi Václava, Viléma a Arnošta došlo brzy po 2. únoru 1434. BIERMANN, G. Geschichte der Herzogthümer Troppau und Jägerndorf. Teschen: Prochaska, 1874, s. 199, upozornil, že se tak muselo stát již před 7. březnem 1435, ze kdy pochází první samostatná listina bratří Viléma a Arnošta. PRIX, Vévoda Václav II. Opavský a Hlubčický (2. část), s. 195, posunul toto další dělení do podzimních měsíců, přičemž jako pravděpodobný termín post quem stanovil zasedání opavského zemského soudu, jež se odehrálo ve dnech 15.-18. záŕí 1434 a na němž bratř̌i vystupovali společně (tamtéž, s. 211-212, pozn. č. 221). Jeho údaje převzal následně také MAMULA, J. Vilém Opavský v zápase o Minstrberské knížectví. Příspěvek k biografii opavsko-minstrberského zeměpána v polovině 15. věku. Slezský sbornik, 2014, 1/CXII, s. 7.

39 Poslední listina, kterou bratři vydali společně jako nedílní vládci Opavska, pochází z 21. ledna 1434. Jak již bylo uvedeno výše, vystupovali Václav, Vilém a Arnošt společně před opavským zemským soudem ještě v září téhož roku, když postoupili Třebovice s př́slušenstvím bratřím Janu Sobkovi a Matěji Bělíkovi z Kornic. RGHT, s. 136-137, č. 481, s. 138, č. 484. Avšak v tomto př́ípadě šlo o dispozici odúmrtí, která jim připadla po smrti jejich švagra Jana Jičínského z Kravař, tedy o majetkoprávní úkon, který vyžadoval souhlas všech bratří. Společné právní jednání není proto v žádném směru v rozporu s hypotézou, že i mladší synové Přemysla I. již v té době měli konkrétně přiřčené díly země.

40 BIERMANN, Geschichte der Herzogthümer, s. 198-199; PRIX, Vévoda Václav II. Opavský a Hlubčický (2. část), s. 195. 
Prakticky vzápětí došlo $\mathrm{k}$ dělení rodového majetku i v ratibořské přemyslovské primogenituře. Výrok devítičlenné šlechtické komise byl vydán 15. ř́ina 1437 a znamenal v podstatě opětovné úplné oddělení Opavska a Ratibořska - mladší Václav III. obdržel Ratibořsko, starší Mikuláš VI. Krnovsko (s Bruntálskem a panstvím Vartnov), k němuž byla od Ratibořska odtržena dominia Pština, Rybnik, Vladislav a Bavorov. ${ }^{41}$ Po Mikulášově smrti pak došlo k další fragmentaci jeho údělu mezi syny Jana V. a Václava V. Listina se $\mathrm{v}$ tomto prŕípadě nedochovala, $\mathrm{z}$ kontextu je ale zřejmé, že rozdíl proběhl v roce 1465 a Janovi v jeho důsledku připadlo Krnovsko s Bruntálem a Vladislaví, zatímco zbylé ratibořské statky Rybnik a Pština se staly doménou Václavovou. ${ }^{42}$

Literatura konečně předpokládá, že po smrti Václava II. v roce 1446 se o jeho pozůstalost neprodleně rozdělili dva jeho synové, přičemž starší (?) Jan III., jemuž se později dostalo přídomku „Zbožný“ 43 obdržel Hlubčicko, mladšímu (?) Janovi IV., v pramenech stabilně vystupujícímu pod jménem Hanuš, připadly statky, jejichž centrem byl Hradec nad Moravicí. ${ }^{44}$ Bohužel, ani v tomto případě se nedochovala listina, z níž by bylo možno bližší povahu tohoto dělení poznat, a život a panování Václavových synů dokumentuje jen dosti malé množství diplomatického materiálu. Na první pohled nápadná je ovšem skutečnost, že jsou dochovány pouze samostatné listiny obou bratrů a neexistuje, pokud je známo, ani jediný dokument, který by vydali společně. Lze tedy mít za to, že si oba sourozenci skutečně sféry vlivu rozdělili, přičemž šlo ale zřejmě pouze o faktickou dohodu a ne o formální rozdíl.

V každém případě je $z$ výše uvedeného přehledu víc než patrné, že původně homogenní Opavské vévodství se v průběhu staletí opakovaně štěpilo mezi mužské př́islušníky přemyslovské dynastie. Některá dělení byla epizodická, jiná se ukázala býti poměrně trvalá. V první řadě je potřeba upozornit na oddělení Krnovska od zbytku Opavska v roce 1377, v jehož důsledku se osudy těchto dvou zemí do značné míry rozešly (byt' povědomí o společném původu přetrvávalo). Krnovsko, poté co se na počátku husitských válek znovu vrátilo do rukou Přemyslovců, zůstalo pevně spojeno s Ratibořskem a při dělení tamních knížat opakovaně představovalo základ jednoho z bratrských dílů. V rámci redukovaného Opavska se pak brzy ukázal význam města Hlubčic, které společně se svým okolím opakovaně tvořily část jednoho z knížecích údělů (poprvé také již v roce 1377).

Vytvoření tří hlavních územních korpusů dosti samostatného charakteru je patrné i z dalších událostí ve druhé polovině 15 . století, kdy Přemyslovci v různém čase a různým způsobem o jednotlivé díly původního rodového knížectví přišli (pouze sousední Ratibořské

41 Český text listiny, jež byla opsána do RSW, fol. 605v-609r, č. 507, publikoval KAPRAS, O státoprávních poměrech Opavska (2. část), s. 48-51, obsáhlý německý regest je v CDS VI., s. 59-61, č. 195, mnohem stručnější v LBS II., s. 394-395, č. 13.

42 KOUŘIL - PRIX - WIHODA, Hrady českého Slezska, s. 522. Zde je také dovozena správná datace rozdílu, který starší literatura kladla do roku 1464 - viz např. KAPRAS, O státoprávních poměrech Opavska (2. část), s. 52. Dělo se tak chybnou interpretací listiny z 9. dubna 1464 - viz RSW, fol. 19v-21r, č. 11, fol. 73v-74v, č. 39; CDS VI., s. 87, č. 268. Mladší Václav se jako samostatný pán na Rybniku poprvé připomíná 9. února 1466. ZIVIERA, E. Geschichte des Fürstentums Plesß. I. Teil: Entstehung der Standesherrschaft Pleß (bis 1517). Kattowitz: Druck und Verlag von Gebrüder Böhm, 1906, s. 186, č. 12.

43 Důvodem je především založení františkánského kláštera v Hlubčicích, jehož fundační listinu vydal Jan 26. zář́i 1448. NA Praha, fond Františkáni Praha, Listiny, sign. 19.

44 KOPETZKY, Zur Geschichte und Genealogie der Přemyslidischen Herzoge von Troppau, s. 57-59, 62-63; KAPRAS, O státoprávních poměrech Opavska (2. část), s. 31. Naposledy KOUŘIL - PRIX - WIHODA, Hrady českého Slezska, s. 496. Pořadí obou synů je nejisté a v literatuře se různí. 
vévodství se dynastii podařilo udržet až do jejího vymření v roce 1521). Nejprve zcizil vévoda Arnošt v polovině padesátých let větší část Opavska (svůj díl a díl svého nedávno zemřelého bratra Viléma, který spravoval jako poručník jeho nezletilých dětí) piastovskému knížeti Boleslavovi Opolskému. ${ }^{45}$ Když získal od Boleslavova bratra Mikuláše v roce 1460 tuto část Opavska král Jiří z Poděbrad, ${ }^{46}$ zaměřil svou pozornost i na zbytek země a posléze dotlačil i vévodu Jana k prodeji části jeho državy. Podle literatury se tak mělo stát v roce 1464, přičemž jako podklad k této dataci je odkazováno na zprávu Bedy Dudíka o listině, která se měla nacházet v pražském archivu maltézského řádu. ${ }^{47}$ Tu se ale již ve druhé polovině 19. století nepodařilo nalézt. ${ }^{48}$ Nelze přitom vyloučit (ba zdá se to dosti pravděpodobné), že šlo o omyl a že Dudík pouze př́iliš volně interpretoval privilegium z 26. ledna 1464, v dotčeném fondu skutečně uložené, jímž Jiříkovi synové Boček, Viktorin, Jindřich a Hynek potvrdili na žádost svého kaplana Valentina oltáři v kapli kostela sv. Jana v Opavě roční plat 10 hřiven grošů, který měl být podle nařízení zesnulého Václava II. Opavského odváděn z „oddielu města Opavy, kterýž sme od kněze Jana, syna jeho, dědičně kúpili““. ${ }^{49}$ Zmínka o prodeji Janova dílu Opavska je také v deskovém zápise z února téhož roku. ${ }^{50} \mathrm{Z}$ těchto zmínek ale jasně vyplývá pouze to, že k prodeji Janova dílu Opavy a hradeckého zboží došlo před uvedenými daty, mohlo se tak ale klidně stát již dříve. A nejspíše i stalo, nebot' obě zprávy implicitně předpokládají, že ke změně situace na Opavsku došlo již před nějakým

45 Arnošt nejprve zastavil Boleslavovi panství Bílovec a následně prodal, nebo rovněž zastavil prakticky celý zbytek Opavska, náležející jemu a jeho synovcům. Př́islušné dokumenty se nedochovaly a Boleslavovy zisky lze rekonstruovat pouze na základě listin, jejichž prostřednictvím převedl jeho bratr a dědic Mikuláš tyto majetky na Jiřího z Poděbrad. Tak se v roce 1460 zavázal Mikuláš králi „dáti a sstúpiti nejprve svú spravedlnost, kterúž jměl na Opavě po kníži Bolko, bratra jeho [sic!] dobré paměti, i list ten, kterýž svědčí na ta dva odtiely [sic!] vosum a dvadcati tisíc zlatých celý a neporušený, Edelštajn hrad, Cukmantel městečko s jeho př́íslušenstvím, tak jakož to kněz Bolek sám držal, a ty listy také dáti, ješto svědčí na tu zástavu, a Bielovic městečko zase vypustiti z toho knižetztvie [sic!] opolského“. Text je přepsán v RSW, fol. 478r-480r, č. 402, obsáhlý regest byl publikován v CDS VI., s. 79, č. 248. Také v dalším listu Mikuláše Opolského z roku 1465 jsou zmíněny ,listy na dva oddiely na knížetství opavské na osmecítma tisíc zlatých svědčiti [sic!] i také listy zástavné na hrad Edlštein a Cukmantel městečko i na př́íslušnosti jich, také list ten na městečko Bielovic i všecky jiné listy“. RSW, fol. 179v-180v, č. 147; CDS VI., s. 89-90, č. 273. KOUŘIL - PRIX - WIHODA, Hrady českého Slezska, s. 495, soudili, že částka 28000 zlatých se vztahovala nejen na dva díly Opavska, ale též na bílovecké zboží a Edelštejn s Cukmantlem, které měl Boleslav v zástavě od Arnoštova bratra Václava II. Avšak skladba obou listin spíše odpovídá tomu, že se tato suma vztahovala toliko na samotnou část Opavy. Pokud jde o Bílovec, ten byl opolským knížatům postoupen o něco dříve a dozajista zástavně. Starší literatura zpravidla zjednodušeně hovořila o prodeji dvou čtvrtin Opavska za 28000 zlatých, viz např. KOPETZKY, Zur Geschichte und Genealogie der Přemyslidischen Herzoge von Troppau, s. 60; BIERMANN, Geschichte der Herzogthümer, s. 209. K správné dataci transakcí opět KOUŘIL - PRIX - WIHODA, Hrady českého Slezska, s. 495.

46 RSW, fol. 478r-480r, č. 402; CDS VI., s. 79, č. 248.

47 KOPETZKY, Zur Geschichte und Genealogie der Přemyslidischen Herzoge von Troppau, s. 62; BIERMANN, Geschichte der Herzogthümer, s. 211; KAPRAS, O státoprávních poměrech Opavska (2. část), s. 37 aj.

48 Srovnej LBS II., s. 508, č. 48. Hodnověrnost Dudíkovy zprávy ostatně podlamuje i fakt, že měl podle ní Jan prodat celé své panství, tedy i Hlubčicko, což se s jinými dochovanými prameny jednoznačně nesrovnává. NA Praha, fond Archiv českého velkopřevorství maltského řádu, Listiny, sign. 2018.

50 KAPRAS, J. (ed.). Pozůstatky knih zemského práva knižetstvi Opavského. Díl I. Knihy předni. Část 1. (1413-1484). Praha: Nákladem České akademie císaře Františka Josefa pro vědy, slovesnost a umění, 1906, s. 68, č. 39 (,že jemu osviecené knieže, kněz Jan Opavský a Hlubčický, to, coš protiv Jeho Milosti a jeho poddaným učinil, odpustil, prve nežli králově M[ilos]ti svuoj oddiel v Opavě a Hradec prodal“). 
časem. ${ }^{51}$ Poslední doklad Janovy vlády v části Opavska je každopádně spojen s rokem 1461, kdy zemský soud nalezl v jednom sporu, že má být důkaz proveden „,pred kniežecí Milostí, knězem Janem, a před hejtmanem královským a před comorníkem". 52

Ve výsledku tak Poděbradové ovládli větší část země a vévodství opavské bylo králem Jiřím uděleno jeho třem synům lenním listem ze 16. prosince 1465, společně s Minstrberským vévodstvím a Kladským hrabstvím. ${ }^{53}$ Jan IV. si podržel Hlubčicko, které po jeho smrti (zřejmě v roce $1483^{54}$ ) spadlo jako odumřelé léno na Matyáše Korvína, který jako jeden z uznaných českých králů vykonával svrchovanost nad vedlejšími zeměmi České koruny. Pokud jde o Krnovsko, toho se Matyáš v roce 1474 zmocnil vojensky a dosavadního vládce Jana V. nechal dožít pouze na vladislavském zboží, které bylo součástí Ratibořska a s Krnovskem bylo spojeno v důsledku bratrského rozdílu z roku 1465. Zatímco Opavsko bez Hlubčicka se po krátké vládě Jánoše Korvína a jagellonského prince Zikmunda a dvacetiletém hejtmanství Kazimíra Těšínského stalo bezprostředním knížectvím, a to až do roku 1614, kdy bylo (jak již bylo uvedeno výše) uděleno coby slezské knížectví Karlovi z Lichtenštejna, Krnovsko a Hlubčicko se záhy sešly pod společnou vládou Jiřího ze Šelmberka (1503) a následně ansbašských Hohenzollernů (1523).

Poměrně obsáhlý exkurz $\mathrm{k}$ dějinám Opavska a k jeho dělení mezi různé vládce byl nezbytným prologem k nastolení klíčové otázky, položené již v titulu této práce. A sice,

51 Martin Čapský dospěl v kolektivní monografii JIRÁSEK, Z. a kol. Hradec v dějinách. Hradec nad Moravicí: Městský úřad Hradec nad Moravicí, 2010, s. 37, k závěru, že k prodeji došlo patrně v roce 1463.

52 Poziostatky knih zemského práva knižetstvi Opavského. Díl I. Knihy prední. Část 1. (1413-1484), s. 62, č. 559.

53 Originál listiny je v AČK, č. 1717; editována je v LBS II., s. 156-158, č. 36. Pozoruhodná je skutečnost, že lenní list se vztahuje pouze na tu část Opavska, kterou Jiř́ koupil od Jana IV., totiž hradecké panství a třetí díl města Opavy (ducatus Oppaviensis videlicet castrum Hradecz et terciam partem civitatis Oppavie). V této souvislosti se nabízí hypotéza, že zbytek Opavska získali Boleslav Opolský a po něm král Jiří pouze jako zástavu, což by vysvětlovalo, proč se na něj lenní list nevztahoval. To by předpokládalo, že teprve po roce 1465 došlo k převedení zástavní držby na vlastnické právo. Bohužel, torzovitost dochovaných pramenů neumožňuje tuto hypotézu dále argumentačně podpořit. Za pozornost ovšem stojí, že ještě v roce 1474 zapsal Viktorin z Poděbrad své druhé choti Žofii Těšínské vdovské věno právě na Hradci nad Moravicí a třetině města Opava. LBS II., s. 511, č. 54.

54 Jan se jako žijící objevuje v listině vratislavského biskupa Jana (IV.) Rotha z 12. srpna 1482. RSW, fol. 365r-366r, č. 291; CDS VI., s. 114, č. 343, s. 216-217, č. XXVII. Toto datum se jako terminus post quem Janova úmrtí běžně objevuje v genealogické literatuře, viz např. v GROTEFEND, H. Stammtafeln der schlesischen Fürsten bis zum Jahre 1740. Breslau: Max, 1875, Tafel XI; WUTKE, K. Stammund Übersichtstafeln der Schlesischen Piasten. Breslau: Ferdinand Hirt, 1910-1911, Tafel VIII; WEGENER, Die Herzöge von Troppau und Leobschütz, Jägerndorf und Ratibor, Tafel 3; či nejnověji KOUŘIL PRIX - WIHODA, Hrady českého Slezska, s. 584-585. S tím celkem koresponduje i orientační datum 1485, jež je obsaženo v pracích CHOCHOLATÝ, Genealogie opavských Přemyslovců 1255-1525, s. 146; či SCHWENNICKE, Europäische Stammtafeln III.1., Tafel 18. Datum Janovy smrti lze ale specifikovat ještě přesněji. Naživu byl totiž ještě 21. prosince 1482, kdy osobně vystavil list, jímž vyslovil souhlas se zabezpečením hlubčického špitálu. PRASEK, V. Historická topografie země Opavské A-K. Opava: Jubilejní fond na vydávání Vlastivědy Slezské, 1889, s. 202-203. Mrtev pak byl nepochybně 19. května 1484, kdy král Matyáš konfirmoval veškerá privilegia města Hlubčic. MINSBERG, F. Geschichte der Stadt Leobschütz. Beitrag zur Kunde oberschlesischer Städte. Neisse: Wangenfield, 1828, s. 155-157, př́loha č. 15. Listina je zmíněna též v konfirmačním privilegiu markraběte Jana Jiř́ho z roku 1609, uloženém v NA Praha, fond Česká dvorská kancelář (= ČDK), Listiny, i.č. 122. REIMANN, G. J. Die Franziskanerkirche zu Leobschütz. Geschichte und Führung. Breslau: Franke, 1939, s. 7, uvedl (žrejmě na podkladě místní tradice), že Jan zemřel na počátku roku 1483, což v zásadě velmi dobře odpovídá výše shrnutým skutečnostem. 
jaké byly dopady shora uvedených dělení v rovině státoprávní. Primárním důvodem výše uvedených aktů bylo vždy uspokojení vladařských ambicí jednotlivých Přemyslovců. Šlo tedy o dohody tak říkajíc dynastické. Rozpadlo se však Opavské vévodství touto cestou skutečně na menší, svébytná knížectví, nebo vedly uvedené dílčí procesy pouze k rozdělení vlády a majetku, aniž by tím došlo k narušení státoprávní integrity vévodství? Nebo ještě jinak, jednodušeji: byly jednotlivé přemyslovské državy knížectvími, nebo šlo jen o části jedné země?

Na první pohled by se mohlo zdát, že nemůže být složité na takto položenou otázku odpovědět. Avšak již jen letmý pohled do dosavadní historiografické produkce nutí ke korigování optimismu. Rozsah a složení souboru slezských knížectví se v jednotlivých pracích často liší, právě podle toho, do jaké míry autoři přikládají jednotlivým dělením státoprávní význam. Vršit jednotlivé příklady by nemělo smysl, pro ilustraci snad postačí poukaz na encyklopedické dílo předního znalce slezské historie, Rudolfa Žáčka, který do části „Územní a správní vývoj Slezska“, zařadil soubor krátkých, abecedně řazených hesel, v nichž ve zkratce vylíčil osudy jednotlivých teritorií, která se ve Slezsku v průběhu staletí vygenerovala. ${ }^{55} \mathrm{~V}$ poznámce předřazené tomuto seznamu nicméně zdůraznil, že dotyčný soupis ,byl pořízen podle dostupné literatury, která se ovšem v detailech (zejména v oblasti právního statutu jednotlivých území, období držby daného území jednotlivými knížaty, společného spravování územního celku více knížaty apod.) někdy i poměrně výrazně lišíi“ a že ,zvláště právní statut není u některých územních celků zcela jasný“.56

Právní historie nebyla dosud při hledání odpovědí na subtilní státoprávní otázky, spojené s roztř́ištěností slezského prostoru, př́liš aktivní. ${ }^{57}$ Pokud jde o Opavsko, jeho právními dějinami se svého času zabýval především profesor Jan Kapras. Obě jeho fundamentální studie jsou zasvěceně zpracované a velmi přínosné, bohužel ale hlubší analýza státoprávního postavení jednotlivých derivátů původního vévodství, konstituovaného v roce 1318 , v nich provedena není. Zejména přehledově uspořádané Opavské právní dějiny doby knížecí z přelomového roku $1918^{58}$ tuto otázku víceméně opomíjejí.

55 ŽÁČEK, R. Dějiny Slezska v datech. Praha: Libri, 2004, s. 410-456.

56 ŽÁČEK, Dějiny Slezska v datech, s. 409. Jako př́iklad poněkud bezradného a nepříliš konzistentního přístupu lze uvést studii KONVIČNÁ, J. Několik poznámek k dějinám pštinského knížectví do roku 1517. In: PAZDEROVÁ, A. - KAHUDA, J. (eds.). Našim jubilantkám (Sborník přispěvků k poctě životního jubilea Věry Beránkové, prom. hist., PhDr. Dagmar Culkové a PhDr. Marie Liškové). Praha: Státní ústřední archiv Praha, 2000, s. 129-134, v níž autorka v rozporu s názvem práce dospívá k správnému závěru, že Pštinsko představovalo od 14. století značně svébytné území, využívané jako vdovské věno pro ratibořské kněžny, až do 16. století bylo ale vždy součástí jiných knížectví.

57 Právní historii slezských knížectví (a svobodných panství) se systematicky věnuje především vratislavský profesor Marian J. Ptak. Zde se sluší upozornit zejména na studii PTAK, M. J. Czy istniało Księstwo Legnicko-Brzeskie? Ustrój polityczny i prawny władztwa Piastów legnicko-brzesko-wołowskich w XVI i XVII wieku. In: Dziedzictwo reformacji w księstwie legnicko-brzeskim. Materiały międzynarodowej konferencji naukowej zorganizowanej w dniach 8-10 grudnia 2005 r. w Muzeum Miedzi w Legnicy (Das Erbe der Reformation in den Fürstentümern Liegnitz und Brieg. Protokollband der internationalen Fachtagung veranstaltet am 8.-10. Dezember 2005 im Kupfer-Museum zu Liegnitz). Legnica: Muzeum Miedzi, 2007, s. 13-21, v níž autor argumentačně dovodil, že nikdy neexistovalo často literaturou uváděné Lehnicko-břežské knížectví, nebot' Lehnicko i Břežsko si přes opakované spojování pod vládu příslušníků jedné z větví piastovské dynastie podržely svojí státoprávní samostatnost. KAPRAS, J. Opavské právní dějiny doby knížecí. Věstník Matice opavské 1918, 24, s. 3-45. 
O několik let starší výklad O státoprávních poměrech Opavska ${ }^{59}$ obsahuje přeci jen několik stručných komentářů na toto téma. Tak v souvislosti s rozdělením země v roce 1377 soudil Kapras, že ,jednotné knížetství nerozpadlo se však na tři samostatná knížetství, nýbrž pouze na tři části, z nichž jen vlastní Opavsko označováno v následující době knížetstvím, kdežto ostatní dvě pravidelně jen zemí (land) nazývány“، 60 O hlubčickém díle, jemuž vládl Mikuláš III., zdůraznil in specie, že „bylo tehdy vždy považováno za pouhou část knížetství Opavského“ a naprosto analogicky zopakoval na jiném místě i o Krnovsku, že ,třebas mělo tehdy již zvláštní organisaci, nebylo považováno za nic více než za část Opavska“ ${ }^{61}$ Když bylo Hlubčicko po smrti Mikuláše III. znovu spojeno s polovinou Opavska, jíž držel Přemysl I., komentoval to Kapras tak, že „přivtělením Hlubčicka neměnilo se na státoprávní povaze ničeho,“ protože Hlubčicko nebylo „považováno za knížetství samostatné, nýbrž jen za část oddělenou pro jednoho člena rodu“. ${ }^{62}$ A konečně i při dalším dělení země mezi Přemyslovy syny bylo podle Kaprase nepochybné, že „Opavsko bylo tedy pouze fakticky na tři části roztrženo, avšak i na dále tvořilo jednotku, z níž pouze Hlubčicko bylo vyzdviženo označením v titulu knížete Václava“. 63

Poněkud méně jednoznačné jsou Kaprasovy glosy vztahující se k pokročilejšímu období po polovině 15 . století. Tak o vládě vévody Jana IV., sídlícího v Hlubčicích, konstatoval, že „Hlubčicko ... v posledních desetiletích značně se osamostatnilo, tak že jako samostatný kraj Hlubčický proti Opavsku jest kladeno“, resp. že „začíná poprvé Hlubčicko i v deskách Opavských býti označováno jako samostatný kraj Hlubčický odlišný od kraje Opavského“. ${ }^{64}$ Obsáhlý komentář o vnitřním vývoji Krnovska pak ze státoprávního pohledu resumoval poukazem na to, že „vzdor tomuto samostatnému vývoji vnitřnímu na Krnovsku nemluví se o Krnovsku nikdy jako o knížetství, nýbrž pouze jako o zemi (lant)“ ${ }^{65} \mathrm{Na}$ první pohled překvapivá a snad až zarážející úspornost této části výkladu je ovšem plně v souladu se zaměřením studie na dobu „knížecí“, kdy Opavsku vládl přemyslovský rod - rozklad jeho panství a nástup nových dynastií již ležely přeci jen stranou Kaprasova zájmu. A tak vlastně jen glosa, že uherský a český král Matyáš Hunyady pojistil v roce 1487 v rámci dohody o zásnubách svého nemanželského syna Jana s Blankou Marií Viscontiovou věno nevěsty „mezi jinými i na knížetstvích Opavském a Hlubčickém“66 dává tušit, že státoprávní postavení Hlubčicka rozhodně nelze popsat jako statické.

K tomu, aby bylo možno Kaprasovy teze (nepochybně velmi fundované, nebot' právními dějinami Opavska a Slezska vůbec se zaobíral dlouhodobě a systematicky) potvrdit, případně korigovat, je ovšem nutno najít obecný interpretační klíč. Tedy pokusit se o teoretické vymezení toho, podle jakých kritérií mají být právní status a míra státoprávní samostatnosti

\footnotetext{
59 KAPRAS, O státoprávních poměrech Opavska (1. část), s. 35-49, (2. část), s. 17-54.

60 KAPRAS, O státoprávních poměrech Opavska (2. část), s. 24-25.

61 Tamtéž, s. 44.

62 Tamtéž, s. 27, 41.

63 Tamtéž, s. 31. V moderní literatuře se lze ale setkat s tvrzením zcela opačným - za všechny srovnej poměrně hojně využivané přehledové dílo WECZERKA, H. Handbuch der historischen Stätten. Schlesien (=Kröners Taschenausgabe, Band 316). Stuttgart: Alfred Kröner Verlag, 2003, s. 276, jež ovlivňuje současnou historiografii prvoplánovým tvrzením, že Hlubčicko tvořilo v letech 1365 (sic!) - 1394 a 1434-1482 „,ein eigenes Fürstentum“.

64 KAPRAS, O státoprávních poměrech Opavska (2. část), s. 33, 39-40.

65 Tamtéž, s. 53.

66 Tamtéž, s. 40.
} 
jednotlivých knížecích údělů vrcholného a pozdního středověku (a ostatně i nastupujícího raného novověku) posuzovány. Teprve vypořádání se s tímto problémem může otevř́it prostor pro smysluplnou analýzu, jejíž výsledky pak mohou být podrobeny další odborné diskuzi.

Je nepochybné, že primárním vodítkem musí být základní dokumenty, jejichž účelem bylo nastavit fundamentální právní vztahy mezi českým králem a slezskými knížaty, resp. mezi těmito knížaty navzájem. Za takové dokumenty lze v prvé řadě považovat lenní listy, dále též kupní, případně zástavní smlouvy, jimiž docházelo k převodu držby celých teritorií. Patřit budou do této skupiny nepochybně i dílčí listy, jimiž docházelo k vypořádání otcovského dědictví mezi jednotlivé příslušníky knížecích dynastií.

Avšak soubor shora vymezených pramenů, jež se do dnešních dob zachovaly bud' v originále, nebo aspoň v opisu a o něž se lze v první řadě opřít, není bohužel nijak zvlášt' rozsáhlý a vykazuje značnou mezerovitost. Ke slovu tak musí přijít i další písemnosti, o něž se svého času velkou měrou opíral i Kapras. Jejich obsah může přitom v zásadě nabídnout dvě argumentační roviny. Na jedné straně je to náhled současníků na status jednotlivých teritorií. Ten ovšem představuje ukazatel subjektivní, který nemusí nutně korespondovat s objektivní právní realitou. Na straně druhé pak může být diskutována míra autonomie vnitřního uspořádání jednotlivých knížecích dominií. Zde ovšem pro změnu platí, že samostatná správa a soudnictví ještě samy o sobě nemusejí nutně znamenat vyšší státoprávní kvalitu a mohou být pouze projevem decentralizace v rámci stále jednotného, navenek nerozděleného knížectví.

Pokud jde o první rovinu, na místě je přihlížet předně k titulatuře jednotlivých knížat, kterou sama používala ve svých listinách. Lze z ní celkem nepochybně dovozovat, jak sami vládci státoprávní status svého teritoria vnímali. ${ }^{67}$ Zároveň je ale zapotřebí vést v patrnosti, že panovnická titulatura mohla odrážet i obsahově prázdné nároky nebo reminiscence na starší mocenskou situaci, jako tomu bylo třeba v př́ípadě minstrberských Poděbradů, kteří užívali titulu kladských hrabat až do vymření rodu v polovině 17 . století, ačkoliv hrabství prodali již v roce 1501 hrabatům z Hardeka. ${ }^{68}$

Podobně subjektivní je také označování jednotlivých teritorií v dalších pramenech, kupříkladu narativní povahy. Z nich lze opět dovozovat přesvědčení autora o státoprávních poměrech, toto přesvědčení se ale i v těchto případech může s realitou více či méně míjet. Je přitom nasnadě, že smysl má zkoumat pouze prameny kontemporální, nebot' jakýkoliv výraznější časový odstup zásadně problematizuje výpovědní hodnotu toho či onoho zdroje, nevyhnutelně vycházejícího z informací nějakým zpơsobem zprostředkovaných.

Z hlediska vnitřního vývoje jednotlivých knížecích údělů je nutno sledovat teritoriální působnost klíčových správních a soudních orgánů - do chvíle, kdy navzdory formálnímu rozdělení přetrvává institucionálně společné zabezpečení veřejné moci, těžko lze uvažovat

67 Pozoruhodnou a metodicky podnětnou práci představuje ve vztahu k interpretaci knížecí titulatury nedávno vydaná monografie GRABOWSKI, J. Dynastia Piastów mazowieckich. Studia nad dziejami politycznymi Mazowsza, intytulacją i genealogią książąt. Kraków: Avalon, 2012, zejm. s. 213-412.

$68 \mathrm{~K}$ tomu je ovšem třeba dodat, že si Poděbradové v kupní smlouvě další užívání hraběcího titulu - byt' „ohne Mittel“ - výslovně vyhradili. Stejně jako později Hardekové, když Kladsko prodali králi Ferdinandovi I. K dějinám Kladska (které mimochodem držel v letech 1397-1422 zástavně opavsko-ratibořský přemyslovský kníže Jan II.) v té době srovnej FELCMAN, O. - HLADKÝ, L. - ŠŮLA, J. Právní postavení Kladska v českém státě do roku 1742 (K ústavněprávnímu, politickosprávnímu a církevněsprávnímu vývoji Kladska). 2. část. Kladský sborník, 1999, III, s. 9-14. 
o existenci skutečně samostatných státoprávních celků. Na druhou stranu je ale zjevné, že vytváření vlastních orgánů v jednotlivých údělech jim ještě samo o sobě státoprávní entitu nedává a že může být pouze signálem postupné, nicméně stále ještě nedovršené decentralizace.

Jinými slovy, veškeré argumenty ohledně státoprávního statusu dominií jednotlivých knížat je vždy nutno posuzovat komplexně. Žádný z nich není možné bezvýhradně absolutizovat, žádný nelze bezdůvodně pominout. S trochou nadsázky to lze vyjádřit tak, že je nutno vycházet ze zásady volného, nikoli formálního hodnocení důkazů. 69 Ta bude nyní postupně aplikována na dvě knížecí državy, které se z původně jednotného Opavska v průběhu 14. a 15. století oddělily, totiž Hlubčicko a Krnovsko.

Počátky jejich samostatných dějin lze hledat v tzv. prvním dělení Opavska, k němuž došlo v roce 1377. Interpretace jeho výsledků je přitom velmi složitá, nebot' výpověd' jednotlivých pramenů není v žádném případě jednoznačná. Samotné dílčí listiny mluví o rozdělení země na dva díly („das wir von Gebotes vnd von Geheise wein derselben vnser Herren das Lant zu Troppaw in zwei Teil geteilet haben“), respektive o rozdělení poloviny země na dva díly (,des haben wir das selbe Halbe Land van irem Geheisse vnd von irem gutten Willen in zwei Teil geteilt“) ${ }^{70}$ nikoli o vzniku nových knížectví. To se zdá poměrně jasně signalizovat, že smyslem tohoto kroku bylo pouze zajistit každému ze synů Mikuláše II. samostatnou sféru vlivu (společná ovšem zůstávala urbura ze zlatých dolů kolem Cukmantlu). Chápání Opavska, byt’ rozděleného, jako jedné entity podporuje na první pohled i následně užívaná titulatura všech čtyř bratří, kteří se shodně označovali jako knížata opavská (dux Oppauiae).

Na druhou stranu je ale třeba pozastavit se u lenního listu, který nedlouho po rozdělení, 17. července 1378, vydal král Václav IV. pro syny z třetího manželství Mikuláše II., Václava a Přemysla. ${ }^{71}$ Již to, že udělení léna neproběhlo současně ve vztahu ke všem čtyřem bratrům, se na první pohled zdá nasvědčovat, že jednotlivé součásti Opavska nastoupily zcela samostatnou cestu. Předmětem udělení léna bylo sice dle textu dokumentu „das Herczogtum und Furstentum zu Troppaw mit seinen furstlichen un herlichen Rechten, Gerichten, Zollen, Lehen, Manschafften, Eygenschafften, Steten, Slossen, Landen, Leuten, Gutern und mit allen iren Zugehorungen“, těžko lze ale pochybovat o tom, že se listina omezovala na tu část země, která adresátům před rokem připadla na základě bratrského dělení. List také zaručoval vzájemný dědický nápad Václava a Přemka, kdy po smrti jednoho bez mužských dědiců mělo knížectví automaticky připadnout druhému z nich. I to mluví spíše ve prospěch hluboké separace jednotlivých podílů - pokud by totiž celé Opavsko mělo de iure fungovat jako společný majetek všech Přemyslovců (tedy prakticky obdoba nedílu ve smyslu českého zemského práva ${ }^{72}$ ), byt's reálně vymezenými podíly pro jednotlivá knížata, nemohli by mít někteří sourozenci při přebírání podílu jiných přednost a musela by fungovat př́sná parita dílů.

Za povšimnutí stojí v této souvislosti i kontrast mezi dvěma listinami olešnického knížete Konráda II., vztahujícími se k dílu Mikuláše III. V roce 1374 slíbil olešnický Piastovec, který

69 Druhá alternativa bývá označována též jako legální teorie důkazní.

70 CDS VI., s. 195-201, č. XIV-XVI; PRASEK, Překlad s výkladem na dílčí listy země Opavské z r. 1377, s. $10-21$.

71 ZA Opava, fond Slezský stavovský archiv Opava (= SSAO), sign. A VI-3, i.č. 5; LBS II, s. 491-493, č. 25.

72 K institutu nedílu naposledy STARÝ, Nedíl, s. 199-206, kde je i přehled starší literatury. 
měl Mikulášův díl Opavska v zástavě, že ho v př́ípadě Mikulášovy smrti vrátí po zaplacení dlužného věna své sestry Hedviky (Mikulášovy matky) ostatním bratřím. ${ }^{73}$ Avšak o devět let později, v roce 1383, se stal adresátem obdobného příslibu již jen nejmladší z Mikulášových bratř́i, Přemysl. ${ }^{74}$ Ten se pak v roce 1394 po Mikulášově smrti skutečně bez odporu ujal jeho pozůstalosti, aniž by jakékoliv nároky vznášeli další žijící př́íslušníci přemyslovské dynastie. Určitou logiku v tom lze spatřovat z toho pohledu, že Přemysl byl posledním žijícím Mikulášovým bratrem a byl tedy jeho bližším kognátem než ratibořští synovci. Pro ně asi nemělo navíc hlubčické dědictví př́liš velkou přitažlivost, nebot' bylo silně zadlužené a jim se nedostávalo prostředků ani na výplatu Krnovska. I tak je ovšem více než patrné, že vzájemné vazby mezi jednotlivými díly Opavska byly již v devadesátých letech 14. století zcela zásadně oslabeny. V majetkovém společenství (byt' zachovávaném toliko ve formálně právní rovině) patří totiž automatická akrescence podílů zbylých členů společenství v př́padě smrti jednoho z nich k nosným principům, které tento právní režim charakterizují.

Také míra samostatnosti při výkonu dispozičních práv k jednotlivým součástem původně jednotného Opavska ze strany rozdělených bratří dalece přesahovala možnosti obvyklé v rodinných majetkových společenstvích. Již sama skutečnost, že dal Mikuláš III. celý svůj díl do zástavy příbuzným z matčiny strany, se v tomto ohledu jeví podezřelou. Jestliže to by ale bylo možno vysvětlit oprávněnými nároky olešnických knížat, vážícími se k jejich nezpochybnitelné a poměrně vysoké pohledávce za Mikulášem II., k jejímuž vyrovnání či zajištění jiným zpo̊sobem se Přemyslovcům nedostávalo prostředků, pak jiné kroky, jimiž jednotlivá knížata řešila svoji finanční tíseň, se takovémuto vysvětlení vymykají. Extrémním případem byl postup knížete Jana II., který v roce 1384 prodal celý svůj podíl Opavska, to jest Krnovsko, opolskému vévodovi Vladislavovi. ${ }^{75}$ Tato transakce byla následujícího roku zpětně schválena i králem Václavem jakožto lenním pánem. ${ }^{76}$

Velkým nebezpečím pro jednotu Opavska byla aktivita moravského markraběte Jošta, který v osmdesátých letech 14. století souběžně usiloval o získání částí země od jednotlivých zadlužených Přemyslovců, s nimiž byl prostřednictvím své matky Markéty Opavské blízce pokrevně spř́źzněn. Souviselo to s jeho snahou soustředit ve svých rukou vládu nad Moravou v celých jejích historických hranicích - kromě mladších bratří mu stáli v cestě olomoucký biskup a právě opavští vévodové. Jejich državy byly totiž v inkorporační listině Karla IV. z roku 1348 prohlášeny za přímá léna českého krále, a tím pádem definitivně odloučeny od státoprávního útvaru Moravského markrabství. ${ }^{77}$

Jošt nejprve obrátil svou pozornost k dílu nejmladšího Přemysla, jehož nouze přinutila dát do zástavy rozsáhlé dominium Hradec nad Moravicí i s rezidenčním knížecím hradem. Jošt se nepochybně nabídl jako věřitel, Přemysl dal ale přednost pánům z Kravař, které

73 RSW, fol. 570r-570v, č. 471, fol. 610r-610v, č. 509; CDS VI., s. 12, č. 53; LBS II, s. 482, č. 21.

74 RSW, fol. 7r-8r, č. 6; CDS VI., s. 15, č. 70.

75 Starší literatura kladla postoupení Krnovska opolskému vévodovi do let 1384-1385 a často se uvažovalo o jeho zástavním charakteru. Avšak podle všeho se jednalo o standardní koupi, k níž došlo ještě v roce 1384, nebot' již téhož roku složilo město Bruntál Vladislavovi Opolskému hold. Blíže KOUŘIL - PRIX WIHODA, Hrady českého Slezska, s. 510-511.

76 RSW, fol. 323v-324r, č. 271; CDS VI., s. 15, č. 69 (23. března 1385); KAPRAS, O státoprávních poměrech Opavska (2. část), s. 44 (pozn. 7).

77 AČK, č. 301. K listině blíže BOBKOVÁ, 7. 4. 1348. Ustaveni Koruny království českého. Český stát Karla $I V$., s. 61-66. Na Joštův nátlak ve vztahu k olomouckému biskupství upozornil přesvědčivě VÁLKA, J. Dějiny Moravy I. Středověká Morava. Brno: Muzejní a vlastivědná společnost, 1991, s. 103-110. 
právem považoval za méně nebezpečné pro své budoucí plány. Jošt ale dosáhl alespoň toho, že mu Přemysl za půjčku hotových peněz přiznal pro př́pad své bezdětné smrti nástupnická práva ve své části Opavska. ${ }^{78}$ Také tento krok, implicitně, avšak zcela zjevně popírající nástupnictví Přemyslových ratibořských prríbuzných, je mimochodem dalším argumentem proti státoprávní jednotě Opavska v této době.

Výrazně úspěšnější byl Jošt v prŕípadě té části země, která při dělení Opavska v roce 1377 připadla právě ratibořské primogenituře a následně byla, jak již bylo zmíněno výše, v roce 1384 knížetem Janem II. odprodána Vladislavovi Opolskému. Jan počal o několik let později usilovat o zpětné vyplacení otcovského dědictví, nebyl ale schopen uspokojit zjevně přemrštěné nároky opolského vévody. Nakonec došlo v roce 1390 k třístrannému jednání, při němž vévoda Jan vykoupil nazpět pouze část země, totiž Bruntálsko s hradem Fürstenwalde, a větší část Krnovska prodal Vladislav právě markraběti Joštovi. ${ }^{79}$ Tomu se tím pádem podařilo rozšířit svrchovanost moravského markraběte i na nemalou část Opavského knížectví. Již první jeho vladařský krok, když 1. března 1390 osvobodil město Krnov ode všech cel a poplatků na Moravě, 80 jasně signalizoval hlavní linii jeho zdejší vnitřní politiky - opětovnou faktickou integraci Krnovska do Moravského markrabství.

Joštův postup ale nebyl v tomto ohledu důsledný, zřejmě především z ohledu na místní politickou reprezentaci, která si po rozdělení Opavska v roce 1377 rychle navykla na výsadní postavení v této části země. Již v roce 1379 se připomíná Aleš z Heraltic, komorník krnovské cúdy („Kammerer der Zuden zu Jägerndorff“), ${ }^{81} \mathrm{z}$ dalších let jsou doloženi též zemský komorník a písař, což nepochybně signalizuje dotvoření samostatného zemského soudu. ${ }^{82} \mathrm{~S}$ tím koresponduje zř́zení úřadu zemského hejtmana, který Jošt svěřil sobě oddanému rytíri Janu Küchenmeisterovi, který v roce 1405 inicioval reformu krnovských zemských desk, vedených ovšem již od samotného rozdělení. ${ }^{83}$ Krnovsko si

78 Srovnej Joštovo prohlášení z 9. dubna 1383, uložené v ZA Opava, fond Archiv města Opava, sign. III/5, i.č. 9. Regest je otištěn v RGHT, s. 107-108, č. 397.

79 Transakce z roku 1390 zachycují dvě listiny Vladislava Opolského: kupní smlouva na Krnovsko, datovaná 28. února 1390, a výpověd' z 10. dubna 1397. Originál první z nich je uložen v AČK, č. 1286. Texty obou jsou in extenzo otištěny v LBS II, s. 494-496, č. 29 a 30, první pak také v CDM XI., s. 511-513, č. 589. Zatímco v kupní smlouvě se cena za Krnovsko stanoví ve výši 11200 kop pražských grošů, ve druhé listině jsou částky přepočítány na polské hřivny a hovoří se zde o 11050 hřivnách za Krnovsko a 10950 hřivnách za Bruntálsko.

80 Text privilegia se dochoval v konfirmaci z poloviny 18. století - viz ZA Opava, Státní okresní archiv (= SOkA) Bruntál, fond Archiv města Krnov, i.č. 1, fol. 13r-13v.

81 SOkA Bruntál, Archiv města Krnov, i.č. 1, fol. 12v.

82 Tak se komorník, cúdař a písař „des Gebitis czu Jegerdorff“ objevují již roku 1404 v úvodním zápise krnovských zemských desk. PRIX, D. (ed.). Zemské desky krnovské. Svazek I. 1403-1522. Opava: Zemský archiv v Opavě, 2008, s. 33-34, č. 1. Viz též KAPRAS, O státoprávních poměrech Opavska (2. část), s. 53.

83 O tom, že iniciativa Jana Küchenmeistera neznamenala zř́zení zemských desk, jak uvedl po vzoru některých starších prací ještě ŠTĚPÁN, Moravský markrabě Jošt, s. 583, nýbrž pouze jejich reformu podle moravského vzoru, podal přesvědčivé důkazy PRIX (ed.), Zemské desky krnovské. Svazek I., s. 20-30. Ten také editoval (s. 92, č. 108) zápis z 6. ledna 1406, který to jasně dokládá (český překlad je na s. 25). Že šlo o pouhou reorganizaci, uvedl ostatně již např. KAPRAS, J. Oberschlesische Landbücher. Ein Beitrag zur Geschichte der öffentlichen Bücher. Zeitschrift des Vereins für Geschichte Schlesiens, 1908, XLII, s. 73 (rovněž zde je edice zápisu z roku 1406); TÝŽ, O státoprávních poměrech Opavska (2. část), s. 53 (kladl ovšem reformu do roku 1404). In margine lze doplnit, že v roce 1407 dal markrabě Jošt Janovi Küchenmeisterovi a jeho bratru Čáslavovi hejtmanský úřad dědičně do zástavy, a to za půjčku 1000 kop grošů. CDM XIII., s. 537, č. 500. 
tak udrželo samostatnou administrativu, nepropojenou se správním aparátem moravským. Na druhou stranu ale sbližování Krnovska s markrabstvím dále pokračovalo, což platilo i o období po bezdětné Joštově smrti. Král Václav IV., který Joštovo dědictví převzal, totiž vydal 22. března 1411 obyvatelům Krnovska konfirmační privilegium, v němž jim garantoval všechna práva, jež požívají obyvatelé Moravského markrabství, a zároveň přislíbil, že po dobu svého života Krnovsko nezcizí od Koruny české a Moravského markrabství. ${ }^{84}$

Sluší se dodat, že podobně jako na Krnovsku, probíhal zřejmě i v hlubčické části Opavského vévodství hned od roku 1377 v oblasti správy a soudnictví emancipační proces, jehož projevem bylo zřízení samostatných zemských úřadů a zemského soudu. Písemné doklady jsou v př́padě Hlubčicka ojedinělé, avšak pro rozhodnutí ve sporu mezi knížetem Mikulášem a jakýmsi Michálkem, jež vynesli „Kamerer, czudener und lantlute zu Lupschicz“ a jež bylo, opatřeno pečetěmi komorníka a sudího, zasláno na Krnovsko, ${ }^{85} \mathrm{se}$ dá těžko hledat odlišná interpretace. ${ }^{86}$

Všechny uvedené argumenty poměrně jasně ukazují na to, že jednotlivé části Opavského knížectví se po jeho rozdělení v roce 1377 začaly vzájemně dosti rychle odcizovat. ${ }^{87}$ Tato tendence ovšem byla částečně zažehnána tím, že v roce 1394 zemřel bezdětný Mikuláš III. a znovu došlo ke spojení hlubčického dílu s polovinou Opavska v rukou Přemysla I.

Dokument, který si v rámci výkladu rozhodně zaslouží delší zastavení, je privilegium Václava IV., vydané pro Přemysla I. a jeho synovce Jana II. a Mikuláše IV. během králova pobytu ve Vratislavi 17. srpna 1404. Text v originále zřejmě nedochované listiny se nachází v tzv. Registru Sancti Wenceslai ${ }^{88}$ a v objemném díle Somersbergově, ${ }^{89}$ podle nějž byl během 19. století vydán ještě ve dvou edičních korpusech. V obou byl přitom označen jako společné oblénění190 a stejně tak je chápán i v literatuře. ${ }^{91}$ Tím je ovšem jeho obsah do jisté míry posunut. Minimálně Přemysl již lenní slib složil dávno předtím (v roce 1378) a dosti

84 SSAO, sign. A VI-4, i.č. 410; LBS II, s. 497-498, č. 34.

85 Blíže nedatovaný rozsudek zpřístupnil TILLER, F. Zur Geschichte der Landrechte der Fürstentümer Jägerndorf und Leobschütz. Schriften der historisch-statistischen Sektion der k.k. mähr. schles. Gesellschaft des Ackerbaues, der Natur- und Landeskunde 1856, IX, s. 133; podle něj též KAPRAS, Oberschlesische Landbücher, s. 75.

86 KAPRAS, Oberschlesische Landbücher, s. 74-75, upozornil v této souvislosti na zprávu o prodeji vesnice Suchá Pština ,,in iure Lubshicensi situatam“, k němuž došlo již v roce 1337. Tato zmínka se ale nezdá dostatečně jednoznačná k tomu, aby bylo možno vyvozovat, že Hlubčicko mělo vlastní soud již za vlády vévody Mikuláše II.

87 Tak také soudil např. BIERMANN, Geschichte der Herzogthümer Troppau und Jägerndorf, s. 218-219, že zrod Krnovského knížectví je třeba datovat k dělení v roce 1377 („war die Trennung des Jägerndorfischen von dem Herzogthum Troppau eine vollständige, und man kann mit vollem Rechte den Bestand eines Herzogthums Jägerndorf von dem Augenblicke an datiren“").

88 RSW, fol. 330v-331v, č. 274.

89 SOMMERSBERG, Silesiacarum rerum scriptores, Tomus I, s. 845.

90 LBS II, s. 496-497, č. 31 („Gesammtbelehnung“, datum je zde chybně přepočteno na 16. srpna); CDM XIII., s. 337, č. 326 („,K[önig] Wenzel belehnt die Herzoge von Troppau“). Regest v CDS VI., s. 24, č. 105, je zpracován podle RSW, fol. 331, č. 274, je zde ale nesprávná datační formule (,der negste Tag [namísto „Sonntag“ - pozn. aut.] nach U[nserer] F[rauen] Tag Assumptionis“, posouvající datum vydání rovněž k 16. srpnu.

91 Namátkou KOPETZKY, Zur Geschichte und Genealogie der Přemyslidischen Herzoge von Troppau, s. 44; KAPRAS, O státoprávních poměrech Opavska (2. část), s. 27. Také SPĚVÁČEK, J. Václav IV. 1361-1419. Praha: Svoboda, 1986, s. 355, pozn. 1, komentoval vratislavské události tak, že král Václav přijal hold tř́i opavských vévodů ,,a udělil jim opavské vévodství jako léno České koruny listinou ze 17. srpna 1404“. 
pravděpodobně se dá předpokládat, že i Jan II. ho někdy v osmdesátých letech napodobil. K udělování léna tak v zásadě chyběl důvod. Královská listina, v naraci právem označená jako mimořádná milost (,besundre Gnade“), ovšem zcela měnila dosavadní právní stav v tom smyslu, že pro futuro prohlašovala všechny země držené oběma přemyslovskými liniemi (ratibořskou i opavsko-hlubčickou) za léno společné (,dass sie alle ire Furstenthumb, Herrschaft, Land und Leute in gesampter Lehn haben, halden und besiczen sollen").

Znamená to, že bylo Opavsko znovu autoritativně prohlášeno za jedinou, nedílnou zemi? Nikoli. Takový výklad nemá v listině oporu. Jednak se vztahovala pouze na aktuální državy Přemyslovců a zcela mimo její dosah tak zůstávalo Krnovsko, nacházející se v této době pevně v rukou markraběte Jošta..$^{92}$ Listina navíc nebyla vůbec omezena pouze na Opavsko, ale zjevně pod režim společného léna subsumovala i Ratibořské knížectví, na které měli dědičné právo pouze potomci Jana I. jakožto synovce posledního ratibořského knížete z rodu Piastovců. ${ }^{93}$ Více než výmluvný je také dovětek k prohlášení všech přemyslovských držav za společné léno - podle listiny měly mít stejný režim, jako by všichni tři její adresáti nebyli odděleni (,gleicherweis als ob sie mit denselben iren Landen und Lüten ungesundert und ungeteilt weren“). Z čehož a contrario jasně vyplývá, že odděleni byli a že tedy na Opavsko po roce 1377 nelze v žádném směru nahlížet jako na společný rodový majetek, který by byl rozdělen pouze fakticky, tvořil ale jednotnou entitu po stránce právní. Ostatně hranice mezi Ratibořskem a Bruntálskem na straně jedné a Opavskem se znovupřipojeným hlubčickým dílem na straně druhé měla existovat i nadále a každá rodina měla nadále svými državami vládnout zcela libovolně.

Hlavním přínosem listiny tak bylo potvrzení dědických nároků mezi jednotlivými liniemi přemyslovské dynastie. ${ }^{94}$ Jak již bylo výše zmíněno, vzájemný dědický nápad jednotlivých synů Mikuláše II. zaručovala již listina Karla IV. z 28. února 1367. Uplynutím několika desetiletí došlo ovšem $\mathrm{k}$ pochopitelnému uvolnění vztahů mezi oběma přeživšími rodovými liniemi, takže znovupotvrzení jejich nároků rozhodně nebylo samoúčelné (byt' by se mohlo de iure zdát zbytečné). Navíc došlo k významnému posunu v tom smyslu, že Karlova listina se týkala pouze Opavska, zatímco nyní došlo k rozšíření tohoto právního režimu i na Ratibořsko.

Zdá se nepochybné, že iniciátorem vratislavského privilegia z roku 1404 byl kníže Přemysl. Jednak se jeho prostřednictvím otevírala i opavské sekundogenituře možnost ujmout se vlády v Ratibořském knížectví, jednak v jeho prospěch hovořila i rodinná situace - zatímco jeho ratibořští synovci byli oba svobodní a bezdětní, ${ }^{95}$ Přemysl sám měl

92 Nelze tedy souhlasit s interpretací, jíž publikoval PRIX (ed.), Zemské desky krnovské. Svazek I., s. 26-27, totiž že Přemyslovci si nechali ,potvrdit vzájemná nástupnická práva ve všech částech bývalého opavského knížectví".

93 V roce 1366, po smrti Mikuláše II., také udělili Karel IV. a Václav IV. Ratibořsko lénem pouze Janovi. RSW, fol. 1r-1v, č. 1 a fol. 92r-93r, č. 54 (listina Václavova), fol. 315r-316r, č. 264 (listina Karlova); krátké regesty jsou v CDS VI., s. 8, č. 35 a 36. Na základě opisu v Moravském zemském archivu je text obou lenních listů in extenzo vydán také v CDM IX., s. 311-312, č. 413-414. Je ovšem třeba připomenout, že lenní listy z let 1337 a 1339 nic o výhradním dědickém právu potomků Mikuláše II. z manželství s Annou Ratibořskou neobsahovaly, jak upozornil již BAKALA, Problematická integrace Opavska s Ratibořskem ve světle listin Jana Lucemburského, s. 73-74.

94 Tento aspekt správně zdůraznil ČAPSKÝ, Vévoda Přemek Opavský (1366-1433), s. 169.

95 V genealogické literatuře se tradičně uvádí, že se Jan II. oženil teprve v roce 1407 s Helenou Korybutovnou, neteří polského krále. Teprve TĘGOWSKI, J. Pierwsze pokolenia Giedyminowiczow. Poznań - Wrocław: 
s manželkou Annou Luckou dva syny blížící se dospělosti. ${ }^{96}$ Dalibor Prix soudil, že listina vlastně směřovala proti markraběti Joštovi, nebot' král Václav „zdůraznil formální svrchovanou nerozlučnost vévodství jako celku, byt' jeho díly byly v držení jednotlivých členů rodu ... a jasně tak dal najevo, že jeho [tj. Joštovu - pozn. aut.] vládu v Krnovsku považuje za epizodickou a nemíní tolerovat jakékoliv pokusy směřující k okleštění nebo narušení integrity Opavska“, čímž listina v konečném důsledku „smetla eventuální Joštovy iluze o možném zpětném přičlenění Opavska k Moravě““.97 Taková interpretace se ale zdá poněkud nadsazená - nové právní poměry jistě představovaly dosti pevnou překážku proti dalším expanzivním snahám moravského markraběte, což byl zřjejmě hlavní důvod, proč se do projektu zapojili i Jan II. a jeho bratr. Na druhou stranu se ale listina dozajista neobracela adresně proti Joštovi a jeho držbě Krnovska (jehož se, jak již bylo řečeno, vůbec netýkala) - markrabě nedlouho předtím poměrně významným způsobem vystoupil proti plánům namířeným proti králi Václavovi, a ten tak dozajista neměl důvod, aby tuto podporu „odměnil“ zpochybněním Joštovy vlády na území, které rádně koupil a zaplatil.

Václavovo privilegium se stalo výchozím bodem pro další kroky, které již podnikli sami vévodové Jan II. a Přemysl I. a které směřovaly k upřesnění podmínek vzájemného dědického nápadu. Již v záŕí roku 1404 na schůzce v městečku Křenovicích obě strany deklarovaly své srozumění s vzájemným dědickým nápadem, ${ }^{98} \mathrm{v}$ roce 1407 pak došlo k uzavření skutečných dědických smluv, jejichž prostřednictvím měly být přemyslovské državy, tj. celé někdejší Opavsko (stále však bez Krnovska, ovládaného Joštem Lucemburským) a Ratibořsko, velmi úzce spojeny. ${ }^{99} \mathrm{~V}$ té době se situace v přemyslovském rodě dále zjednodušila, nebot' kníže Mikuláš, jemuž byla v roce 1405 postoupena k samostatné vládě polovina bruntálského panství, ${ }^{100}$ krátce nato zemřel a naživu zůstávali skutečně již jen Jan II. a Přemysl se svými syny.

Wydawnictwo Historyczne, 1999, s. 85-86, upozornil, že se Jan již v polovině devadesátých let 14. století oženil s jinou Jagellovou př́buznou, dcerou kyjevského a posléze kopylského a słuckého knížete Vladimíra († po 1398). O trvání tohoto manželství, z něhož nevzešli žádní potomci, se nedostává zpráv; zdá se ale velmi pravděpodobné, že Janova první chot' zemřela před rokem 1404.

96 Přemyslovo manželství bylo uzavřeno již před rokem 1386, kdy se Přemysl objevuje s označením ,unsern lieben Schwager“v listině vlodiměřsko-luckého knížete Fjodora (†1431). ZA Opava, fond Pozůstalost Františka Tillera, i.č. 3. Blíže též STARÝ, M. Anna „von der Luczka“ (K původu první manželky vévody Přemysla I. Opavského). In: STARÝ, M. (ed.). Genealogia ac heraldica Bohemica. Praha: Česká Genealogická a Heraldická Společnost, 2002, s. 57-65. V době, kdy došlo k vydání společné listiny pro ratibořské i opavské Přemyslovce byla Anna ještě naživu, nebot' téhož dne, 17. srpna 1404, vydal král Václav souhlas k převedení jejího vdovského věna na opavský hrad, ves Kylešovice a další majetkové př́islušenství. SEDLÁČEK, A. (ed.). Zbytky register králův řimských a českých z let 1361-1480. (= Historický archiv 39), Praha: Česká akademie císaře Františka Josefa, 1914, s. 71, č. 459.

97 PRIX, Vévoda Václav II. Opavský a Hlubčický (1. část), s. 156-157.

98 O jednání z 30. záŕí se dochovala zmínka v dodnes bohužel v originále nedochované Chronicon Oppaviense - viz CHF, fol. 25r-26r. Zatímco BIERMANN, Geschichte der Herzogthümer Troppau und Jägerndorf, s. 183, soudil, že obě strany vydaly při této př́iležitosti listiny, uvedl nověji ČAPSKÝ, Vévoda Přemek Opavský (1366-1433), s. 169, že ze schůzky nevzešla ,žádná společně zpečetěná listina“, což se skutečně zdá být pravděpodobnější.

99 Text smluv se nachází v RSW, fol. 8v-15v, č. 7 a 8. Regesty jsou v CDS VI., s. 27 a 28, č. 112-113, v LBS II., s. 390-394, č. 11 a 12, je plný text listiny Janovy a regest Přemyslovy.

100 CDS II., s. 48-50, č. 49. Vzhledem k tomu, že předmětem dělení bylo v tomto případě jediné panství a jeho centrální hrad Fürstenwalde zůstal - stejně jako některé př́ijmy ze samotného města Bruntálu - oběma bratřím společný, těžko uvažovat v tomto případě o nějakém výraznějším státoprávním rozměru tohoto 
Velmi podrobné reciproční listiny z roku 1407 se již nezabývaly jen vzájemnou dědičností, dostatečně pojištěnou královskou listinou zpřed tří let, ale šlo v nich též o zabezpečení ženských př́islušnic vymřelé linie, spolupráci při vojenských aktivitách (vzájemná pomoc, umožnění průtahu vojska jedné strany přes území druhé) a především o neztenčování komorních statků. V prŕípadě potřeby směli signatáři prodávat či dávat do zástavy pouze vesnice, nikoli hrady a města (výjimku tvořily případy nouze, kdy bylo ale k zatížení třeba i souhlasu druhé smluvní strany). Omezeno bylo také právo odkazovat majetek církevním institucím i světským služebníkům. Spory a nejasnosti měly být řešeny arbitrárně zástupci obou dominií. Obě rodové linie si ovšem zachovaly svou svébytnost a tvrzení, že jejich země jsou zemí jedinou (,sollen die selbigen unnser beiden Lande bei einander bleiben unnd ein Landt sein“), bylo mnohem spíše vznosnou proklamací, než odrazem právní a politické reality. ${ }^{101}$ Navíc po několika letech došlo postupně k vypovězení smlouvy jak ze strany Jana II. (1416), tak i Přemysla (1422). ${ }^{102} \mathrm{~K}$ tomu je ovšem třeba doplnit, že toto vypovězení zrušilo platnost integrujících (v praxi ostatně nejspíš nijak zvlášt’ důsledně dodržovaných) článků, aniž by se ale dotklo vzájemného dědického nápadu, vyplývajícího z královského listu z roku 1404. Totéž lze mutatis mutandis prohlásit i o skutečnosti, že na počátku roku 1420 přijali Jan i Přemysl své země z rukou krále Zikmunda jako léno samostatně. 103

Shodou okolností krátce předtím, než i vévoda Přemysl rezignoval na původní dohodu (a jistě k tomu nemalou měrou přispěla skutečnost, že i jeho synovci se $\mathrm{z}$ druhého manželství narodili dva synové), se do rukou Jana II. vrátila krnovská část Opavska. Také král Zikmund potvrdil sice po smrti Václava IV. 22. ledna 1420 tamním obyvatelům jejich privilegia, zejména garanci být zachováni ,by der Crone zu Behem und Lantrechten zu Merhern“, 104 to mu ale nebránilo v tom, aby Krnovsko vzápětí nezcizil. Novým držitelem se stal břežský kníže Ludvík, jemuž bylo prodáno za 55000 rýnských zlatých bez 4000 kop grošů, které obdržel od vratislavských a svídnických židů. ${ }^{105}$ Zatímco pro Ludvíka ale nemělo Krnovsko jiný význam než způsob zajištění jeho pohledávek vưči králi, ${ }^{106}$ ratibořský Přemyslovec měl o část rodné země svých předků enormní zájem a vyvinul intenzivní a posléze i úspěšnou aktivitu směřující k jejímu získání.

aktu. Tím spíše, že samo od Krnovska odtržené Bruntálsko ani nevykazovalo obvyklé rysy svébytného knížectví, nemělo vlastní soudní a správní organizaci atd.

101 Symbolickým projevem dočasného sblížení obou linií se stalo i vytvoření nového sekretního typáře vévody Přemysla - jeho otisk je znám z listiny z 3. dubna 1407 a na pečeti je čtvrcený štít, v němž se polcený znak Opavska střídá s ratibořskou (hornoslezskou) orlicí. NA Praha, fond Řád maltézských rytírů - listiny, i.č. 1983; na listinu upozornil PRIX, Vévoda Václav II. Opavský a Hlubčický (1. část), s. 157.

102 CHF, fol. 28r-28v, 30r-30v.

103 GRÜNHAGEN, C. Die Hussitenkämpfe der Schlesier 1420-1435. Breslau: Ferdinand Hirt, 1872, s. 15.

104 SSAO, sign. A VI-5, i.č. 415; LBS II., s. 498-500, č. 35.

105 SSAO, sign. B XXI-1, i.č. 416; LBS II., s. 500-502, č. 36. V literatuře je tato transakce někdy interpretována jako zástava, avšak v listině se výslovně mluví o prodeji. Právní režim nicméně nebyl příliš odlišný, nebot' Zikmund si pro sebe i další české krále vyhradil právo zpětné koupě (,wiederkaufu“) za stejnou cenu, a to jak od Ludvíka či jeho dědiců, tak i od kohokoliv, komu by bylo Krnovsko dále prodáno (přičemž prodáváno mělo být opět jedině za výše uvedenou částku). 15. července 1421 potvrdil Ludvík zdejším obyvatelům privilegia. SSAO, sign. A VI-6, i.č. 417.

106 Ostatně stojí za zmínku, že pokud jde o kupní cenu za Krnovsko, byla z větší části řešena započtením a břežský kníže na oplátku vrátil Zikmundovi panství Trenčín, které měl od něho v zástavě v částce 40000 rýnských zlatých. 
Okolnosti tohoto významného znovurozšsiřrení přemyslovského dominia nejsou dodnes úplně jednoznačně rozklíčovány. Jisto je, že 22. března 1422 udělil král Zikmund Janovi Krnovsko lénem ${ }^{107}$ a ten pak potvrdil s několikaměsíčním odstupem zemským stavưm jejich privilegia -13. září městu Krnov ${ }^{108}$ a následně 20. záŕí celé obci („Rittere und Knechte und dy gancze Lantschaft zu Jegerdorf“). ${ }^{109}$ Dne 16. ř́jjna 1422 kvitoval Ludvík Břežský Jana ze zaplacení kupní sumy, jež je př́slušnou listinou uváděna ve výši 8664 kop pražských grošů. ${ }^{110} \mathrm{~V}$ minuciózním díle o hradech českého Slezska, jehož součástí je i podrobný výklad středověkých dějin tohoto teritoria, se uvádí, že Jan držel Krnov již v záŕí 1421, kdy měl posílit posádku ve městě 50 jezdci. ${ }^{111}$ Avšak tzv. grotkovský zápis, který starší literatura kladla do roku 1421, ${ }^{112}$ byl ve skutečnosti sjednán až v roce 1427, po Janově smrti. ${ }^{113}$ Předání Krnovska tak lze ve světle uvedených dat najisto předpokládat až v roce 1422.

Velmi dobře tomu odpovídá i kontext dalších událostí, jejichž byl Jan II. Ratibořský aktérem. První z nich představuje zajetí husitských poslů doprovázených polskými šlechtici, které se odehrálo na počátku záŕí 1421 v Ratiboři. ${ }^{114}$ I starší literatura zpravidla soudila (a nezdá se, že neprávem), že tímto riskantním krokem, který nalezl velmi negativní ohlas u Janových polsko-litevských př́buzných, se ratibořský kníže snažil si krále Zikmunda zavázat. ${ }^{115}$ Zřejmě v souvislosti se svou snahou získat Krnovsko, k čemuž logicky muselo dojít teprve později. Především je ale třeba upozornit, že prakticky zároveň s nabytím Krnovska pozbyl Jan Kladsko, které měl od roku 1397 v zástavě. Jeho zdejší vláda je naposledy doložena v květnu 1422, v srpnu již držel Kladsko jako Zikmundův hejtman východočeský magnát Půta z Častolovic. ${ }^{116}$ Je dosti zřejmé, že oba majetkové převody jsou velmi úzce propojeny a že zajetí husitských poslů předchozího roku sice přineslo ratibořskému knížeti Zikmundovu vděčnost, rozhodně ale nebylo samo o sobě impulzem

107 SSAO, sign. B XXI-2, i.č. 418; LBS II., s. 502-503, č. 37; listina je stručným regestem zmíněna též v SEDLÁČEK (ed.), Zbytky register králuv, s. 118, č. 827. KOUŘIL - PRIX - WIHODA, Hrady českého Slezska, s. 515, pozn. 38, uvedli, že Sedláček datoval listinu o udělení města a hradu „Gagersdorf“ lénem do roku 1421 a před březen 1422, ve skutečnosti je ale u regestu uvedena správná datace a dokonce i odkaz na Grünhagenovu a Markgrafovu edici.

108 SOkA Bruntál, Archiv města Krnov, i.č. 1, fol. 23v-25v.

109 SSAO, sign. A VI-7, i.č. 419.

110 SSAO, sign. B XXI-3, i.č. 420; LBS II., s. 503, č. 38.

111 KOUŘIL - PRIX - WIHODA, Hrady českého Slezska, s. 515, pozn. 39.

112 Např. GRÜNHAGEN, Die Hussitenkämpfe der Schlesier 1420-1435, s. 56-57.

113 Z novější literatury k této problematice ČAPSKÝ, M. Spolek slezských knížat a jeho pokus o společnou obranu jižní hranice Slezska proti husitům (Poznámky k významu a datování šotkovského sněmu). In: BOROVSKÝ, T. - JAN, L. - WIHODA, M. (ed.). Ad vitam et honorem. Profesoru Jaroslavu Meznikovi prátelé a žáci $k$ pětasedmdesátým narozeninám. Brno: Matice moravská, 2003, s. 341-350; BERAN, Z. Landfrýdni hnutí v zemich České koruny. Snahy o zajištěni veřejného pořádku a bezpečnosti ve středověké společnosti. České Budějovice - Hradec Králové: Veduta, 2014, s. 69-70.

114 Blíže KOPETZKY, F. Die Gefangennahme der hussitischen Gesandten in Ratibor. Zeitschrift des Vereins für Geschichte und Alterthum Schlesiens, 1869, IX, s. 209-217; GRÜNHAGEN, Die Hussitenkämpfe der Schlesier 1420-1435, s. 61-65.

115 Např. BIERMANN, Geschichte der Herzogthümer Troppau und Jägerndorf, s. 221-222. KOPETZKY, Zur Geschichte und Genealogie der Přemyslidischen Herzoge von Troppau, s. 72, naproti tomu soudil, že Jan zřejmě jednal na Zikmundův př́íkaz nebo přinejmenším přání.

116 BRETHOLZ, B. (ed.). Geschichtsquellen der Graffschaft Glatz. VI. Band. Heft 2. Die Urkunden im Glatzer Ratsarchiv. Glatz: In Commission J. Franke, 1927, s. 10-11, č. 24; ŠANDERA, M. Dějiny Kladska od zástavy Janu II. Opavsko-Ratibořskému po vznik hrabství. In: 550 let hrabstvi kladského. 550 lat hrabstwa kłodzkiego. Trutnov: Muzeum Podkrkonoší v Trutnově, 2009, s. 80. 
k tomu, aby král postoupil do jeho rukou rozsáhlé území, které krátce předtím prodal někomu jinému. To by navíc byla přespříliš velkorysá odměna za projev podpory, který byl ve svých konečných politických důsledcích přinejmenším problematický. Nehledě na to, že Jan podle listiny z ř́ijna 1422 očividně Ludvíkovi Břežskému za Krnovsko nemalou částku na hotovosti vyplatil.

Kombinací výše rekapitulovaných okolností, o nichž svědčí dodnes dochované písemnosti, lze nejspíše předpokládat, že někdy na počátku roku 1422 došlo k výplatě břežského knížete, přičemž Jan ale poskytl v hotovosti jen část dohodnuté ceny a zbytek na svá bedra převzal král Zikmund. Ve chvíli, kdy byla tato transakce dovršena a Jan obdržel na Krnovsko lenní list, vrátil králi „na protiúčet“ Kladsko. ${ }^{117}$ Je otázkou, nakolik měl na tomto novém uspořádání poměrů zájem sám panovník - Jan dozajista splňoval Zikmundovy představy, že má Kladsko v neklidných časech držet spolehlivý muž, který by „oplýval i diplomatickými a vojevůdcovskými schopnostmi“, a je otázkou, zda panovníkovi bylo skutečně a priori proti mysli, aby Kladsko držel slezský kníže. ${ }^{118}$ Pokud, pak mohl být z královy strany problematický spíše dosavadní charakter Janovy správy, která se nevyznačovala přemírou zájmu o svěřené území a jejímž hlavním motivem bylo vylepšení vlastní ekonomické situace s pomocí prŕíjmů, které z něj plynuly.

Každopádně určitě nedošlo k tomu, že by „věčně zadlužený Lucemburk knížete vyplatil tak, že mu náhradou poskytl Krnovsko“119 - už z toho prostého důvodu, že Zikmund pánem Krnovska nebyl a nikomu ho tedy poskytnout nemohl. Stejně tak nerozkrývá celý komplex transakcí ani jednoduchá představa Franze Kopetzkého, že Zikmund vyplatil půjčenými penězi Krnovsko od Ludvíka a následně ho udělil (za odměnu) Janovi. ${ }^{120}$

Tak či onak, vrátilo se Krnovsko v roce 1422 do rukou Jana II. Opavsko-Ratibořského. Již výše bylo dokumentováno, že hned od rozdělení Opavska v roce 1377 začala jeho krnovská část směřovat k vlastní identitě, což posílila dvě dekády trvající vláda markraběte Jošta a vlastně i pokračující spojení s Moravou po jeho smrti. Jaký obrázek o dobovém chápání statusu Krnovska přitom nabízejí dochované dokumenty? V lenním listu pro Jana II. z března 1422 se hovoří o tom, že Zikmund udělil Janovi „Sloss und Stat Jegersdorff mit allen und iglichen iren Mannen, Landleuten, Leuten, Zinsen, Rechten und Gulten, Welden, Wildpannen, Püschen, Streuchen, Wysen, Weyden, Fischereyen, Teychen, Eckern, Bergen, Talen, Wassern, Wasserleufen und allen andern Unsern Rechten und Zugehorungen“. Označení jádra udělovaného majetku jako ,zámek a město“a navazující podrobný výčet příslušenství odpovídající obratům obvyklým v př́ípadě udílení šlechtických dominií rozhodně žádným způsobem neevokují státoprávní svébytnost léna. Avšak o rok dříve při prodeji Krnovska Ludvíkovi Břežskému se hovoří o „Land und Stat Jegerdorff“ a totožný obrat je použit také v kvitanční listině Ludvíka Břežského z řŕjna 1422. Pojem ,země“ samozřejmě nelze chápat

117 K tomu lze dodat, že není dochována lenní listina na Kladsko a o výši zástavní sumy se lze dohadovat pouze na základě skutečnosti, že v roce 1401 dostal mladší moravský markrabě Prokop právo vyplatit od Jana Kladsko (k němuž byla připojena též frankenštejnská vikpilda) za 4000 kop pražských grošů. ŠTĚPÁN, Moravský markrabě Jošt, s. 520.

118 ŠANDERA, M. Zikmundovi věrní na českém severovýchodě. České Budějovice: Veduta, 2005, s. 61-62; TÝŽ, Dějiny Kladska od zástavy Janu II. Opavsko-Ratibořskému po vznik hrabství, s. 79.

119 ŠANDERA, Dějiny Kladska od zástavy Janu II. Opavsko-Ratibořskému po vznik hrabství, s. 79.

120 KOPETZKY, Zur Geschichte und Genealogie der Přemyslidischen Herzoge von Troppau, s. 74-75. Tuto tezi převzal beze zbytku KAPRAS, O státoprávních poměrech Opavska (2. část), s. 46-47. 
v moderním slova smyslu, na druhou stranu ale poměrně jasně signalizuje, že Krnovsko bylo mnohem víc než jenom rozsáhlé panství. Nota bene, jeho území sestávalo z nemalé části ze svobodných či lenních šlechtických statků a jeho držba tak kromě prímého panství zahrnovala i výkon svrchovaných práv, prríslušejících panovníkovi.

Určitě si také zasluhuje zmínku, že ve dvou konfirmacích ze září 1422 užil ratibořský vévoda v intitulaci poprvé označení „Herzog zu Troppaw, zu Ratibor und zu Jegerdorff“, tedy vévoda opavský, ratibořský a krnovský. Vzhledem k tomu, že z někdejšího Opavska mu patřilo právě jen Krnovsko (s nímž bylo neprodleně znovu spojeno bruntálské zboží), je nutno titul vévody opavského chápat jako označení rodové, užívané všemi Přemyslovci bez ohledu na jejich konkrétní držbu (objevuje se i ve druhé polovině 15. století u Janových potomků, kteří vládli výhradně v Ratibořsku a na Opavsku jim nepatřila ani píd’ půdy), zatímco ,vévoda krnovský“ byl titul nově přijatý, odrážející Janovo opětovné ovládnutí tohoto specifického území. Podobně se i Ludvík Břežský při přijetí holdu a konfirmaci privilegií zemských stavů z roku 1421 psal „Herzog in Slesien, Herre zum Brige, zu Lignicz und zu Jegerdorff“. ${ }^{121}$

Je pravda, že samo označení „vévodství krnovské“, popř́ípadě „knížectví krnovské“ se v dané době neobjevuje a že samo Krnovsko se zásadně označuje ,jen“ jako země. ${ }^{122}$ Otázkou ale je, zda lze tuto skutečnost samu o sobě považovat za postačující doklad toho, že Krnovsko svébytným státoprávním celkem nebylo. A pokud bylo, pak vyvstává otázka, jak jinak lze jeho status popsat, než ho prohlásit za samostatné knížectví? Dezintegrace Opavska byla již na takovém stupni, že lze krnovskou přemyslovskou državu jen stěží vnímat - i s ohledem na její naprostou správní a soudní emancipaci - jen jako fakticky oddělenou část stále jednotného Opavského knížectví. Tím spíše, že listina o společném charakteru udělených lén, jejíž vydání vedlo roku 1404 k dočasnému sblížení obou linií přemyslovského rodu a jejich dominií, se právě na Krnovsko nevztahovala.

Jediná smysluplná alternativní interpretace by mohla směřovat $\mathrm{k}$ úvaze o integraci Krnovska do knížectví ratibořského. Tomu by mohla do jisté míry nasvědčovat i změna v titulatuře ratibořských Přemyslovců - zatímco Janův prvorozený syn Mikuláš se zpočátku psal podle otcova vzoru „Herzog zu Troppau, Ratibor und Jägerndorf“, ${ }^{123}$ od roku 1428 vládli společně s mladším bratrem Václavem již jen jako knížata opavská a ratibořská. ${ }^{124}$ A jistě se v této souvislosti také nelze nepozastavit u dílčí listiny, která byla 15. ř́ijna 1437 uzavřena mezi Janovými syny. Její vydavatelé, oběma knížaty vybraní „zemané a manové ratibořský, krnovský a rybnický“ hned v naraci své listiny zdůraznili, že byli vybráni, aby „ty země, jakožto ratibořskú, krnovskú a rybnickú mezi Jejich Milosti na dvé rozdělili“،, přičemž staršímu Mikulášovi přidělili podle následného výčtu město Krnov, panství Bruntál, Vartnov, Pštinu, hrad Rybnik ,i tu všechnu krajinu rybnickú“ s panstvím Vladislav

121 SSAO, sign. A VI-6, i.č. 417; obdobně též v privilegiu pro město Krnov, jehož opis je v SOkA Bruntál, Archiv města Krnov, i.č. 1, fol. 21r-23r.

122 Patřičně to, jak již bylo výše uvedeno, zdůraznil KAPRAS, O státoprávních poměrech Opavska (2. část), s. 47.

123 SOkA Bruntál, Archiv města Krnov, i.č. 1, fol. 27v-29v; na listinu dále upozornili např. WELTZEL, A. Geschichte der Stadt und Herrschaft Ratibor. Ratibor: Verlag von Max Muschik, 1881, s. 91; BIERMANN, Geschichte der Herzogthümer Troppau und Jägerndorf, s. 223; KAPRAS, O státoprávních poměrech Opavska (2. část), s. 47-48 aj.

124 S doklady KAPRAS, O státoprávních poměrech Opavska (2. část), s. 48. 
a panství Bavorov, na Václava pak zbylo sídelní město Ratiboř se vším příslušenstvím „a panstvím gbitu a země ratibořskej“. ${ }^{125}$ Pozoruhodná je zde především skutečnost, že Krnovsko bylo postaveno na roveň se „zemí rybnickou“, přičemž město Rybnik s okolím tvořilo ovšem od pradávna integrální součást Ratibořska a nic nenasvědčuje tomu, že by se v jeho rámci těšilo výraznější autonomii v oblasti práva či organizačního zajištění veřejné moci. Z toho lze s patřičnou opatrností usuzovat, že Krnovsko bylo při dělení v roce 1437 chápáno jako součást jednotného Ratibořska a označení „,země“ mělo především sloužit k vymezení obou teritorií, jež byla vydělena pro staršího z přemyslovských bratří.

Jak zmenšené Ratibořsko, tak spojený krnovsko-rybnický úděl fungovaly od roku 1437 jako svébytné státoprávní celky, což je patrné i z toho, že byly jako léno českými králi udíleny samostatně. ${ }^{126} \mathrm{Nic}$ na tom nezměnilo období poručenské správy, kterou po Mikulášově smrti vykonával na Krnovsku a Rybnicku jeho přeživší mladší bratr, čímž byla vláda v obou oddělených celcích nakrátko opět fakticky spojena. V roce 1465 pak byla atomizace majetku ratibořské přemyslovské primogenitury dovršena dalším dělením, v jehož důsledku se Krnovsko s připojeným panstvím Vladislav osamostatnilo a bylo odevzdáno Mikulášovu staršímu synovi Janovi. Vzhledem k tomu, že se dílčí listina v tomto př́ípadě nedochovala, je možno pouze hypoteticky předpokládat, že režim dělení byl podobný jako o čtvrtstoletí dříve v předchozí generaci ratibořských Přemyslovců. Jan každopádně ve svém dominiu vykonával zcela samostatnou vládu, a to až do doby, kdy byl Krnovska v roce 1474 králem Matyášem zbaven a byla mu ponechána toliko Vladislav, kde v ústraní dožil.

Krnovsko se mělo stát součástí rozsáhlého slezského panství Matyášova nemanželského syna Jana, nečekaná smrt uherského a českého krále ale pohřbila i tento velkorysý projekt. ${ }^{127} \mathrm{~V}$ listině z roku 1487, jíž mělo být zaručeno věno Janovy snoubenky Blanky Marie Sforzové, je mezi jinými knížectvími jmenováno ducatus Vuladislaviensis ${ }^{128}$ - jedná se tu nepochybně o Krnovsko, přičemž jeho neobvyklé označení je třeba nepochybně přičíst skutečnosti, že právě Vladislav (Wodzisław Śląski) byla poslední knížecí rezidencí zesnulého Jana Krnovského (†1483). Po Matyášově smrti v roce 1490 se vlády v zemi ujala spolu se svým manželem sestra Jana Krnovského, kněžna Barbora, která v roce 1491 potvrdila městu Krnov privilegia. ${ }^{129}$ Král Vladislav Jagellonský ale vnímal Krnovsko jako odumřelé léno a v roce 1493 ho udělil českému nejvyššímu kancléři, Janovi ze Šelmberka.

125 RSW, fol. 605v-609r, č. 507; KAPRAS, O státoprávních poměrech Opavska (2. část), s. 48-51.

126 Tak hned na konci roku 1438 přijal Mikuláš Krnovsko-Rybnický od Albrechta lénem svůj díl, zatímco jméno Václava Ratibořského se v seznamu slezských knížat, která Habsburkovi holdovala ve Vratislavi, neobjevuje (nepochybně proto, že předtím - byt' pod nátlakem a podmíněně - přislíbil podporu polské kandidatuře).

127 Blíže např. FUKALA, R. Slezsko. Neznámá země Koruny české. Knižecí a stavovské Slezsko do roku 1740. České Budějovice: Veduta, 2007, s. 139-140; RADEK, D. Zeměpanské strategie Matyáše Korvína v prostředí slezských knížat. Slezský sborník, 2015, 2/CXIII, s. 207-229; ČAPSKÝ, M. - RADEK, D. Paralela ke zhořeleckému vévodství? K rodové politice Matyáše Korvína v Horním Slezsku. Historie - otázky problémy, 2015, 1/VII, s. 172-179.

128 LBS I., s. 33, č. 19.

129 SOkA Bruntál, Archiv města Krnov, i.č. 1, fol. 29v-32r. Osobě kněžny Barbory byly v nedávné době věnovány dvě samostatné studie - viz KOZÁK, P. Skon Barbory Opavské a Ratibořské, posledního zástupce rodu Přemyslovců na krnovském knížecím stolci. Časopis Matice moravské, 2017, 2/CXXXVI, s. 269-280; STARÝ, M. „... pojav k svatému manželství jich sestry dceru“. Marginálie ke genealogii slezských knížat a k osudům Krnovska na přelomu 15. a 16. století. Časopis Matice moravské, 2018, 1/ CXXXVII, s. 57-85. 
V lenní listině je předmět právního pořízení definován jako „alle Unser Gerechtikait, womit Uns die als Kunige zu Beheim und Herzoge in Schlesien an Czwilin, Jegersdorff Stat und Schloss und dem ganczen selben Fürstenthumb ... angefallen ist"“. ${ }^{130}$ I když není ani v tomto dokumentu užito výslovného označení „Krnovské knížectví“, které nelze chápat tak úplně jako státoprávní název v moderním slova smyslu, je z něj patrné, že tak bylo v dobové politické i právní praxi vnímáno. Termín „Fürstenthum“ je totiž naprosto jednoznačný a nepochybné je také to, že Krnov tvořil jádro tohoto knížectví, byt' knížecí rezidencí nebyl zřejmě krnovský hrad, ale nedaleký Cvilín, připojený ke Krnovsku v polovině 15 . století. Kromě původu pak již toto knížectví nemělo prakticky nic společného s Opavskem, jehož vývoj se od poloviny 15. století ubíral značně odlišnými cestami.

Kolize nároků kněžny Barbory a českého nejvyššího kancléře našla řešení ve sňatkovém spojení mezi oběma rodinami - Barbořina jediná dcera, kněžna Helena Osvětimská, se v roce 1498 provdala za kancléřova nejstaršího syna Jiř́ího ze Šelmberka. ${ }^{131}$ Mezi Jiřím a Barborou došlo zároveň ke specifickému rozdělení vlády, jež našlo svůj odraz v donedávna neznámé smlouvě, uzavřené již předchozího roku. ${ }^{132} \mathrm{~V}$ roce 1506 (22. května) pak Vladislav Jagellonský vydal Jiřímu ze Šelmberka další privilegium, v němž mu přiznal - i s poukazem na jeho spř́znění s přemyslovským rodem - tatáž práva, jakým se těšili vládci ostatních slezských knížectví („,ěch svobod, kterýchž jsú nadepsaná kniežata opavská a ratibořská užievali a podnes užievají“). ${ }^{133}$ Ani toto privilegium, ani genealogické spříznění se slezskými knížecími rodinami ale neznamenaly statutární vzestup Šelmberků ve šlechtické hierarchii - Jiří sice na Krnovsku a k němu připojenému Hlubčicku vykonával vládu (zpočátku společně se svou tchýní, po její smrti pak již zcela samostatně), avšak nebyl knížetem a tituloval se pouze „Herr des Fürstenthums Jägerndorf und Leobschütz“. ${ }^{134}$ Krnovsko ovšem jako svébytné knížectví (zcela nezávislé na Opavsku, které v té době držel králův bratr Zikmund Jagellonský' ${ }^{135}$ ) dozajista vnímáno bylo, ostatně

130 Na základě vidimusu z roku 1529 uloženého ve Vídni byl text listiny in extenzo vydán v LBS II., s. 526-527, č. 71. Opis lenního listu je dochován v Staatsarchiv (= StA) Nürnberg, fond Fürstentum Brandenburg-Ansbach, Herrschaftliche Bücher, Nr. 29, fol. 35v-36v, pozdější opis z 18. století se nachází též v ČDK, sign. II A 4, i.č. 590, kart. 186.

131 Blíže k osudům Krnovska v této době naposledy STARÝ, ,... pojav k svatému manželství jich sestry dceru“, s. 57-85. Zde je také rozebráno vročení sňatku, který někteří starší autoři kladli již do roku 1492.

132 StA Nürnberg, Fürstentum Brandenburg-Ansbach, Brandenburger Literalien, č. 970, fol. 8r-8v.

133 Originál česky psaného listu, podle něhož byl zpracován obsáhlý regest v LBS II., s. 534, č. 79, je uložen v SSAO, i.č. 458, sign. B XXI-5. Dochoval se též vidimus purkmistra a rady Starého Města pražského z roku 1528, uložený v NA Praha, Česká dvorská kancelář, Listiny, i.č. 33. Německý překlad, označený ovšem jako opis („Abschriefft“) je v ČG-L, i.č. 583, sign. L II 462. Obě dvě jazykové varianty se nacházejí v knize, uložené v StA Nürnberg, Fürstentum Brandenburg-Ansbach, Herrschaftliche Bücher, Nr. 29, fol. $58 \mathrm{r}-60 \mathrm{r}$ (německý text), 83r-85v (český text).

134 Tak např. v listině z 25. února 1506, jíž společně s Barborou postoupili všechna svá práva na Landek, Hlučín a Křenovice svým př́ibuzným, ratibořským přemyslovským knížatům Mikulášovi, Janovi a Valentinovi. RSW, fol. 101v-102r, č. 65; CDS VI., s. 154-155, č. 462.

135 K Zikmundově vládě na Opavsku zasvěceně a přehledně KOZÁK, P. Zástavní pán nebo „freyer Fürst“? Několik poznámek k opavské vládě Zikmunda Jagellonského. Acta historica Universitatis Silesianae Opaviensis, 2008, 1 (= Confinia Silesiae. K životnímu jubileu Rudolfa Žáčka), s. 87-97; TÝŽ, Princ Zikmund Jagellonský hlohovským a opavským knížetem. Příspěvek k dějinám politické komunikace na přelomu středověku a raného novověku. In: Średniowiecze Polskie i Powszechne, 2010, 2 (6), s. 224-231; TÝŽ, Zikmund Jagellonský. Králův bratr na opavském knížecím stolci. Vlastivědné listy Slezska a severni Moravy, 2011, 1/XXXVII, s. 6-10. 
i v citované listině z roku 1506 je tak označeno a bylo též výslovně zařazeno mezi knížectví slezská, ${ }^{136}$ čímž se s Opavskem rovněž rozešlo.

Situace, kdy knížectví bylo v rukou příslušníka panského rodu, který držel knížectví, mohl uplatňovat knížecí práva, ale knížetem nebyl, se může z dnešního pohledu jevit prapodivná a ani ve své době nebyla rozhodně obvyklá - s výjimkou poněkud nejasného udělení dolnoslezského Minstrberska Půtovi z Častolovic (†1435) v době husitských válek $^{137}$ šlo o první případ tohoto druhu. Na druhou stranu, několik př́padů, kdy čeští či moravští šlechtici drželi jednotlivá knížectví nebo jejich části zástavně, už slezské prostředí znalo, a Šelmberkův vzestup tak nevzbudil zásadní rozruch. Nic také nenasvědčuje, že by měl problém uplatnit se mezi urozenějšími partnery v rámci knížecího sněmu, resp. dalších celoslezských institucí.

Rozsáhlé šelmberské panství ve Slezsku totiž vznikalo až přiliš velkoryse a od samého počátku na dluh. Finanční závazky začaly zřejmě pronásledovat již Jana, který měl ale jako nejvyšší kancléř př́lišs velkou autoritu a politický vliv, než aby si věřitelé dovolili nějaký důraznější postup. Pozice jeho syna byla v tomto směru o poznání slabší. A tak po vzestupu přišel neodvratný pád. Nepochybně z finančních důvodů prodal Jiří se svými syny v roce 1523 Krnovsko braniborsko-ansbašskému markraběti Jiřímu. O tři roky později zemřel a jeho synové se vrátili na Moravu, kde během nedlouhé doby rovněž zemřeli - bez většího majetku, bez výraznějšího podílu na veřejných záležitostech a bez potomků. ${ }^{138}$

Kupní smlouva, kterou Šelmberkové uzavřeli s markrabětem Jiřím (jehož jako plnomocník zastupoval bohumínský hejtman Petr z Königfeldu) 14. května 1523, je ovšem vystavěna dosti překvapivě. V rámci specifikace předmětu smlouvy se totiž vůbec o Krnovském knížectví, resp. o knížectví vůbec nehovoří, ale dosavadní držitelé markraběti prodávají hrad Cvilín, města Krnov a Hlubčice, městečka Benešov a Bavorov a 24 jmenovitě určených vesnic. V dalším textu se pak předpokládá postoupení a převzetí „,panství““.139 Samozřjmě, podrobný výčet převáděného majetku byl z hlediska právní jistoty více než vhodný, i tak je ale úzkostlivé vyhýbání se termínu „knížectvi““ zarážející. Tím spíše, že

136 Pokud byla v listině explicitně vypočítána panství, která Jiří držel, není to nijak na překážku tomu, aby mohla být dohromady vnímána jako jeden státoprávní celek.

137 Půta držel Minstrberské knížectví jako zástavu od roku 1429 - viz Archiv český čili staré písemné památky české i moravské (= AČ), díl I., s. 534, č. 214; LBS II., s. 145-146, č. 27. V roce 1434 mělo dojít k převedení knížectví do Půtovy dědičné držby - viz regest otištěný v AČ I., s. 534, č. 215. Avšak kdokoliv by knížectví od Půty obdržel, měl být opět jen držitelem zástavním, navíc kvalitu Půtovy držby zpochybnil jeho vlastní list z 30. záŕi 1434, jíž slíbil kdykoliv Minstrbersko opět prodat císaři či jeho nástupcům proti zaplacení zástavní částky 6000 kop grošů. AČ VI., s. 431-432, č. 35; LBS II., s. 147, č. 29; k osobnosti Půty z Častolovic viz zejména ŠANDERA, M. Půta z Častolovic - integrující činitel česko(kladsko)slezského pohraničí. In: Korunni země v dějinách českého státu I. Integrační a partikulární rysy českého státu v pozdním středověku. Sborník přispěvkủ přednesených na kolokviu pořádaném dne 4. června 2002 na FF UK. Ústí nad Labem: Pro ústav českých dějin FF UK Praha nakl. Albis International, 2003, s. $275-292$.

138 K potomkům Jiřího ze Šelmberka srovnej STARÝ, ,... pojav k svatému manželství jich sestry dceru“, s. 73-76.

139 Originál listiny o prodeji Krnovska Jiřímu Braniborsko-Ansbašskému se patrně nedochoval. Opis česky psané smlouvy se nachází v StA Nürnberg, Fürstentum Brandenburg-Ansbach, Herrschaftliche Bücher, Nr. 29, fol. 62r-68r (nenadepsáno, na konci popis „Abschrifft der Kauffberedung über Jegerdorff“). Obsáhlý německý regest na základě textu v kopiáři, uchovávaném v 19. století v Berlíně, je v LBS II., s. 547-549, č. 97. 
by se z hlediska koncepčního nabízelo rámcové vymezení předmětu prodeje (knížectví krnovské) a jeho následné podrobnější rozvedení do položek, reprezentujících jednotlivé majetkové hodnoty. Co více, také listina, kterou svému bratranci ${ }^{140}$ vydal 6 . dubna 1523 král Ludvík Jagellonský, obsahuje předběžný souhlas s tím, že Jiří pojal úmysl koupit ve Slezsku panství Krnov a další zboží („die Herrschafft Jegerndorff und andere Gutter in Unserm Furstenthumb Schlesien gelegen zu kaufen genaigt und gesonnen“"). ${ }^{141}$

Je ovšem mimo jakoukoliv pochybnost, že převáděné území bylo již ve své době chápáno jako samostatné lenní knížectví, čemuž odpovídaly i předchozí právní akty. Pro pochopení dikce listin z roku 1523 je třeba si uvědomit širší kontext slezské politiky jagellonských králů, která se na sklonku 15. a v první čtvrtině 16. století zmítala mezi několika mlýnskými kameny - kromě samotných slezských stavů, které se v zemi chtěly zařídit podle svého, sem dosahoval silný vliv jejich českých kolegů a stranou nezůstávaly ani stavy uherské, hájící stanovisko, že až do vyplacení zástavní částky, dohodnuté v tzv. Olomoucké smlouvě z konce roku 1478, ${ }^{142}$ zůstávají Morava, Slezsko a Lužice součástí koruny svatoštěpánské. Střetávajícím se tlakům odpovídala listinná produkce jagellonských králů, která byla obsahově značně rozkolísaná, ba i zcela protimluvná - podle toho, kterému vlivu právě Vladislav II. a Ludvík podléhali. Velkým vítězstvím slezských stavů bylo tzv. Velké privilegium z roku 1498 (28. listopadu), v němž jim bylo garantováno, že vrchním slezským hejtmanem musí být vždy některý z tamních knížat. ${ }^{143} \mathrm{~V}$ roce 1510 (11. ledna) ale vyšel z české dvorské kanceláře jiný majestát, jímž Vladislav slíbil, že vrchním slezským hejtmanem a stejně tak zemskými hejtmany v bezprostředních knížectvích (Svídnicko, Javorsko, Hlohovsko, Opavsko) a fojtem v Horní i Dolní Lužici smějí být pouze Češi. ${ }^{144}$ Do toho náhle následujícího roku 1511 (3. května) uznal král jiným majestátem, že až do vyplacení zástavy zůstávají Morava, Slezsko a obě Lužice přivtělené

140 Matkou markraběte Jiř́iho byla Žofie Jagellonská (†1512), mladší sestra krále Vladislava II.

141 Ani tato - jazykově německá - listina není známa v originále. Opisy lze nalézt v StA Nürnberg, Fürstentum Brandenburg-Ansbach, Herrschaftliche Bücher, Nr. 29, fol. 10r-11r a 40r-40v, v RSW, fol. 527v-528v, č. 429 a také v ČDK, sign. II A 4, i.č. 590, kart. 186. Regest v CDS VI., s. 171, č. 511, je jen velmi stručný; naproti tomu v LBS II., s. 549-550, č. 98, byl na základě berlínského kopiáře text povolení otištěn in extenzo (s datací chybně přpočtenou na 18 . května).

142 Olomoucká smlouva je vlastně reprezentována třemi listinami, uloženými v AČK, č. 1758-1760: podmínkami formulovanými Vladislavovými vyslanci 28. března 1478 v Brně, přistoupením krále Matyáše k podmínkám dohodnutým vyslanci obou králů (došlo k němu 30. záŕí 1478) a nakonec veřejným vyhlášením úmluvy na olomoucké radnici 7. prosince. Druhá listina byla vydána v AČ IV., s. 488-495, č. 22; konečný dokument pak v AČ V., s. 377-387, č. 13. Definitivní uzavření míru na základě uvedených podmínek se odehrálo 21. července 1479 Olomouci a dosvědčují je dvě listiny krále Matyáše, vydané toho dne. AČK, č. 1761 a 1762.

143 Dobové opisy jsou v ČG-L, i.č. 535 a 536, sign. L II 415a/1 a L II 415a/2; další se nachází např̀. v Hauptstaatsarchiv Dresden, fond Geheimer Rat (Geheimes Archiv), sign. Loc. 10343/25. Plný text privilegia byl otištěn již v LBS I., s. 49-53, č. 29. Jeho obecnější zhodnocení provedl např. ORZECHOWSKI, K. Rola przywileju króla Władysława z 1498 r. w dziejach ślaskiego stanowego parlamentarzymu. In: Vladislavské zřizeni zemské a počátky ústavního zřizení v českých zemich (1500-1619). Sborník príspěvků z mezinárodní konference konané ve dnech 7.-8. prosince 2000 v Praze. Praha: Historický ústav Akademie věd České republiky / Ústav právních dějin Právnické fakulty Univerzity Karlovy, 2001, s. 153-163.

144 AČK, č. 1869, dobový opis je v ČG-L, i.č. 617, sign. L II 503/1, tamtéž pod i.č. 618-619, sign. L II 503/2 a L II 503b jsou německé překlady ze 16. století; obsáhlý regest podle jiného dobového překladu, uloženého ve Wrocławi, je v LBS I., s. 55-56, č. 33. Kompletní text majestátu otisk1 KALOUSEK, J. České státní právo. Praha: Bursík a Kohout, 1892, s. 574-576. 
k Uherskému království. ${ }^{145}$ Po jeho smrti ovšem nabyli opět převahy Češi a vynutili si dvě privilegia krále Ludvíka z roku 1522 - prvním bylo 18. záŕí zrušeno velké slezské privilegium z roku 1498, ${ }^{146}$ druhým byla 29 . ř́ijna obecně potvrzena všechna privilegia, která českým stavům udělil král Vladislav (tedy především ono výše zmíněné z roku 1510). ${ }^{147}$

Jediné logické vysvětlení toho, proč se v souvislosti s prodejem Krnovska v roce 1523 všichni zainteresovaní důsledně vyhýbali zmínky o knížectví, byl zřejmě rostoucí vliv Jiř́ho-Braniborsko Ansbašského, který nebyl po chuti mnoha čelním představitelům české stavovské obce. Markrabě totiž již v roce 1512 přistoupil k dědické smlouvě mezi piastovským knížetem Janem I. a jeho synovcem, posledním opavským Přemyslovcem Valentinem I., ${ }^{148}$ což před ním potenciálně otevíralo výhled na získání rozsáhlých držav v Horním Slezsku - ani starý opolský kníže, ani tělesně postižený Valentin, který byl Jiřího vrstevníkem, totiž nebyli ženatí a neměli přirozené pokrevní dědice. Vedle toho usiloval braniborsko-ansbašký markrabě - neúspěšně - také o dolnoslezské Hlohovsko. ${ }^{149}$ Tyto jeho aktivity budily v Čechách i ve Slezsku zlou krev, jejímž výrazem se stal i text výše zmíněného majestátu z roku 1522, v němž král Ludvík musel slíbit, že nepřipustí, aby na kohokoliv třetího přešel majetek nejbohatšího z hornoslezských knížat, Jana I. Opolského (,,a zvláště knížectví opolského a ratiborského ani žádného toho zboží a statku, což má a drží osvícený Hanuš, kníže Opolské a Horního Hlohova etc., dávati a zapisovati, zastavovati ani odcizovati žádným obyčejem nemáme žádnému, kteréhož by koli důstojenství a stavu anebo národa byl, nežli sami to po smrti jmenovaného knížete Hanuše v Naše ruce vzíti a držeti k Našemu a Našich dědicův a budúcích a Koruně české k dobrému a k užívání“).

Pokud Jiří Braniborský vzápětí koupil od Šelmberků Krnovsko a ucházel se o jeho udělení lénem, šlo nepochybně o velmi citlivou záležitost. Byl-li jeho zisk navenek prezentován jako nabytí běžného šlechtického panství, nikoli státoprávního celku na úrovni

145 Blíže KALOUSEK, České státní právo, s. 85-86.

146 AČK, č. 1946.

147 AČK, č. 1947; text editoval KALOUSEK, České státni právo, s. 576-577. V jeho díle je také velmi přehledné a dobře zpracované pojednání o složitém poměru mezi Čechami a Slezskem v době jagellonské (Tamtéž, s. 83-87 a 94-95).

148 RSW, fol. 503r-505v, č. 420, fol. 515v-525v, č. 427; CDS VI., s. 161-162, č. 482-484. Opis souhlasné listiny krále Vladislava z 11. ř́́jna 1512 je v ČG-L, i.č. 674, sign. L II 540, originál dohody Jiř́ího a Valentina Ratibořského z 31. ř́ijna téhož roku se nachází v AČK, č. 1894.

149 K mocenské invazi Hohenzollernů do Slezska srovnej především NEUSTADT, L. Die ältesten Ansprüche der Hohenzollern auf Schlesien. Jahres-Bericht der Schlesischen Gesellschaft für vaterländische Kultur, 1895, LXXIII (III. Abtheilung, Historische Section), s. 35-52; FUKALA, R. Hohenzollernové v evropské politice 16. století. Mezi Ansbachem, Krnovem a Královcem (1523-1603). Praha: NLN - Nakladatelství Lidové noviny, 2005; přehledně též BORAS, Z. Hohenzollernowie i ich dążenia do opanowania Śląska w drodze umów o przeżycie (w początkach XVI w.). Studia z dziejów Polski, Niemec i NRD XVI-XX w. Poznań, 1974, s. 53-65. Speciálně na otázku opolského dědictví jsou zaměřeny studie FUKALA, R. Zápas o opolsko-ratibořské dědictví a mocenské aspirace slezských knížat na prahu novověku. Slezský sbornik, 2002, 2/C, s. 81-102; a HOLÁ, M. Panovník, čeští stavové a Jiří Braniborský ve sporu o konfirmaci braniborsko-opolsko-ratibořských nástupnických smluv v letech 1528-1531. In: Ve znameni zemí Koruny české. Sbornik k šedesátým narozeninám prof. PhDr. Lenky Bobkové, CSc. Praha: Casablanca, 2006 s. 97-111. Slezské državy ansbašských Hohenzollernů podrobně zmapoval JEGEL, A. Die schlesischen Besitzungen der fränkischen Hohenzollern. Zeitschrift für Geschichte und Kulturgeschichte Schlesiens, 1915, X, s. 85-179. 
knížectví, mohlo to alespoň pro forma poněkud otupit předvídatelný odpor českých stavů. ${ }^{150}$ Což ovšem nic neměnilo na tom, že šlo o transakci jednoznačně protiprávní: již Vladislavovo výše citované privilegium z roku 1510 totiž obsahovalo jednoznačný prŕslib, „aby nižádný z poddaných Našich v těch zemiech nic nemohl dáti, prodati ani zastaviti žádnému cizozemci, bud' knížatům ř́ŕšským aneb jiným, nižádným vymyšleným obyčejem, tak a proto, aby skrze mocné lidi ty země a knížetství napřed jmenovaná od Koruny české a Království českého, od Nás i od budúcích Našich, králův českých, odtržena a odcizena nikterakž býti nemohla“, a i když v Ludvíkově listině z roku 1522 se obdobný zákaz výslovně neobjevil, implicitně byl obsažen v konfirmaci starších privilegií. ${ }^{151} \mathrm{Z}$ tohoto pohledu se svrchu formulovaná hypotéza o tom, proč se výše citované dokumenty v roce 1523 vyhnuly označení Krnovska za knížectví, nemusí zdát dokonale přesvědčivá. Lepší vysvětlení se ale zřejmě nenabízí. Pro úplnost je třeba dodat, že ještě v roce 1523 vydal Ludvík Jagellonský pro Jiřího Braniborského další dvě listiny týkající se Krnovska - nejprve mu 3. července potvrdil držbu a postoupil mu též královská práva na bruntálské panství, ${ }^{152}$ 28. července pak prridal i královské př́ijmy z tamních daní. ${ }^{153} \mathrm{~V}$ obou těchto listinách už se bez jakýchkoliv rozpaků hovoří o Krnovsku jako o knížectví. ${ }^{154}$ Jako takové se pak v rukou Hohenzollernů zařadilo mezi knížectví (horno)slezská. Tento jeho status se pak nezměnil ani v 17. století, kdy bylo personálně znovu spojeno s Opavskem v rukou Lichtenštejnů. ${ }^{155}$

Také Hlubčicko, jak již bylo řečeno výše, započalo po rozdělení synů Mikuláše II. v roce 1377 vlastní cestu dějinami, což podtrhlo prakticky neprodlené vytvoření vlastního soudu a systému úrudů. Na rozdíl do Krnovska ale nevedl vývoj k prohlubování emancipace, ale právě naopak - když v roce 1394 zemřel Mikuláš III., převzal jeho zadlužený a zčásti do zástavy odevzdaný úděl Přemysl I. a opět ho spojil s dalšími dvěma čtvrtinami země, které představovaly jeho vlastní podíl na otcovském dědictví. Součástí této

150 NEUSTADT, Die ältesten Ansprüche, s. 15, uvedl dokonce v souvislosti s udělením Krnovska a zboží Bohumín (rovněž získaného v roce 1523), že byly plánovány úklady o Jiř́iho život.

151 Obě listiny navíc obsahovaly obdobná ustanovení, jejichž jádrem byl zákaz zcizování jakýchkoliv částí České koruny. To je ovšem poněkud jiný případ, nebot' výše uvedený závazek se vztahoval i na situace, kdy by bylo některé území cizím knížatům propůjčeno jako léno České koruny. Pro úplnost budiž dodáno, že ve Vladislavově majestátu je dokonce obsažen i závazek krále, že jakékoliv odumřelé slezské knížectví bude ponecháno v př́imé držbě českých králů, tedy nebude znovu udělováno lénem.

152 Ludvíkova listina je obsažena ve vidimusu heilbronnského opata Jana z roku 1529 a též v konfirmaci krále Ferdinanda I. z roku 1532, jakož i v dalších potvrzovacích královských listinách z let 1557 a 1570. ČDK, Listiny, č. 39, 42, 74 a 79. Podle ve Vídni uloženého originálu je zpracována úplná edice v LBS II., s. 550-551, č. 99 .

153 ČDK, Listiny, č. 28.

154 V prvním př́padě je to zejména v naraci (,wie sein Lieb das Furstenthumb Jhegerndorff sampt aller Zuund Eingehorung, wie es weilenndt die Fursten zu Jhegerndorf innegehabt, genossen und gebraucht ... erblich erkaufft habe“), ale i na dalších místech, ve druhé listině je jádrem dispozice odevzdání „die Stewer so Unns itzundt im Furstenthumb zu Jegerdorff mit seiner Zugehorung gefallen wirdt, gegeben und zugeeyget".

155 Opavsko obdržel Karel z Lichtenštejna na přelomu let 1613-1614, Krnovsko mu pak bylo uděleno v roce 1623, přičemž ve stejný den (13. května) mu byl vystaven i obnovený lenní list na Opavsko. WEBER, M. Das Verhältnis Schlesiens zum Alten Reich in der Frühen Neuzeit. Köln - Weimar - Wien: Böhlau, 1992, s. 195-196; BRŇOVJÁK, J. Lichtenštejnové a jejich knížecí tituly v 17.-18. století. Genealogické a heraldické listy, 2017, 3/XXXVII, s. 13-21 (1. část), 2017, 4/XXXVII, s. 6-13 (2. část). 
reintegrace byla podle všeho cílená likvidace autonomních hlubčických institucí. ${ }^{156}$ Avšak ani tento programový postup již nemohl zpochybnit jistou svébytnost hlubčického regionu, která měla při vhodné př́ležitosti znovu ožít.

Konkrétně našla svou odezvu nedlouho před husitskými válkami, kdy sám Přemysl svěřil některé statky na Hlubčicku jako apanáž svému prvorozenému synovi Václavovi (II.). ${ }^{157}$ Toto uspořádání si zřejmě podrželo platnost i během následujících náboženských konfliktů; zdají se tomu alespoň nasvědčovat události z roku 1428, kdy se Václav poddal husitské přesile „cum civitate Hlubschicz et Hradec“. 158 Opět jde o zprávu nedostatečně konkrétní, neumožňující poznat rozsah Václavovy zástupné správy - s jistotou se ale rozšíŕila i na starobylý knížecí sídelní hrad Hradec nad Moravicí, jehož obléhání, a zřejmě i dobytí, se Václav svou kapitulací moudře vyhnul. Každopádně se Hlubčice znovu staly centrem samostatného vévodského údělu na počátku roku 1434, kdy se po Přemyslově smrti o svůj podíl na otcovském dědictví důrazně přihlásil jeho druhorozený syn Mikuláš (V.). Dílčí listina z 2. února 1434 vypočítává podrobně př́islušenství, které připadlo k jeho dílu, jehož centrem byl hrad Edelštejn a ekonomickým základem města Cukmantl a Hlubčice. ${ }^{159}$ Nicméně v tomto prípadě nebylo provedené dělení zdaleka tak důsledné, jako v roce 1377. Mikuláš i jeho bratři měli rovným dílem těžit z výnosu zlatých dolů a z platu, za který byl městu Hlubčicím předchozího roku prodán knížecí mincovní regál, společně měli vykonávat vrchní práva nad nárokovanými zbožími Fulnek a Odry a také měli společně vyplatit nejmladšího bratra Přemysla II. a zajišt'ovat věnný plat své macechy, kněžny Heleny. Především ale listina výslovně a naléhavě zdůrazňovala zachování jednotného zemského práva, k němuž měli příslušet poddaní všech čtyř bratrů, jichž se dělení týkalo. ${ }^{160}$

Není sporu o tom, že ustanovení týkající se správy země a fungování zemského práva prosadila do listiny opavská šlechta, jejíž politický vliv od předešlého dělení v roce 1377 razantně zesílil. Pokud Dalibor Prix nazval tyto články ,jakýmsi ,zemským zřízením opavským‘, prosazeným do dokumentu stavovskou obcí, která se tak snažila zesmluvnit dualistický vztah mezi vládnoucím rodem a zemskou obcí “, ${ }^{161}$ lze snad tomuto vzletnému vyjádření vytknout (byt' v něm bylo užito uvozovek) př́liš velkorysé užití pojmu „zemské zřízení“, spjatého v běžném slova smyslu se základními kodifikačními počiny. Dozajista ale

156 Ve vztahu k hlubčickému zemskému soudu to výslovně konstatoval KAPRAS, O státoprávních poměrech Opavska (2. část), s. 27.

157 V roce 1416 si Václav půjčil od města Hlubčic v souvislosti se svou chystanou cestou do Porýní a Flander částku 500 hřiven grošů moravského počtu, které jim pojistil platem ze svého dvora před městem a př́imy, které mu z města plynuly. MINSBERG, Geschichte der Stadt Leobschütz, s. 136-137, př́loha K; RGHT, s. 119, č. 435. Otázkou rozsahu Václavových práv na Hlubčicku se zabýval PRIX, Vévoda Václav II. Opavský a Hlubčický (2. část), s. 160, který zřejmě správně usoudil, že soubor zdejších Václavových práv „,rozhodně nenabyl podoby samostatné vlády ve vyčleněném údělu“, nýbrž mu „byla svěřena jen pravomoc nakládat s apanáží, kterou mu otec na Hlubčicku vykázal“. Rozsah této apanáže přitom není možné ani rámcově rekonstruovat, nebot' jejím odrazem je toliko citovaný zápis z roku 1416.

158 Uvádí to Kronika starého kollegiata pražského, vydaná v rámci EMLER, J. (ed.). Fontes rerum Bohemicarum, Tom. VII. Praha: Nákladem Nadání Františka Palackého, [s. d.], s. 32; blíže PRIX, Vévoda Václav II. Opavský a Hlubčický (1. část), s. 169-170.

159 CDS VI., s. 55-57, č. 188.

160 RSW, fol. 602r-605v, č. 506 („Item o řádu zemským, o tom takově rozhodujem, a[by] jeden úřad zemský jako od davodávna (sic!) vždy býval, k němužto zemané všech knížat slušeti mají a sjezditi jse obyčejem od dávna zachovaným“").

161 PRIX, Vévoda Václav II. Opavský a Hlubčický (2. část), s. 194. 
nelze popřít, že šlechta Opavského knížectví dávala prostřednictvím tohoto dokumentu jasně najevo svou představu o dalším fungování rozdělené země, jíž se příslušníci vládnoucího přemyslovského rodu museli přizpůsobit. V každém prŕípadě je ovšem zřejmé, že separace jednotlivých dílů měla v roce 1434 o poznání slabší charakter, než tomu bylo o sedmašedesát let dřive, a že integrita Opavska zůstala do jisté míry zachována. Ostatně je třeba poznamenat, že oddělením Krnovska se knížectví značně zmenšilo a že Přemyslovo dědictví již bylo příliš malé na to, aby z něj bylo možno reálně vytvořit čtyři svébytná knížectví. Výmluvně to dokládá skutečnost, že bylo mezi bratry na čtyři díly rozděleno i samo město Opava.

Kromě odporu šlechty zachránil Opavsko od úplné dezintegrace také následující vývoj, kdy kníže Mikuláš postoupil jen několik měsíců po svém oddělení edelštejnsko-hlubčický díl svému staršímu bratrovi Václavovi ${ }^{162}$ a Vilém s Arnoštem zřejmě spravovali své díly společně. 163

Otázku, zda dělením v roce 1434 vzniklo či bylo obnoveno samostatné knížectví hlubčické, lze ve světle shora řečeného patrně zodpovědět negativně. Hlubčicko bylo spojeno s dílem Opavska pod vládou Václava II. a následně i jeho synů - minimálně po nějakou dobu. Je pravda, že vláda v této části rodové domény našla svůj odraz v knížecí titulatuře: tak se psal Václav již 6. ledna 1435 Wenceslaus, dei gratia dux et dominus Oppawie et in Lupschicz, ${ }^{164}$ také při zástavě Edelštejnu a Cukmantlu v roce 1440 se tituloval „Václav, z Buoží milosti kníže opavské a pán hlupšický“, vesměs se ale nazýval prostě již jen vévodou opavským a hlubčickým ${ }^{165}$ a stejného titulu užívali i oba jeho synové. ${ }^{166}$ Stejně tak

162 Jako pán města Hlubčic vystupuje Václav již v září 1434. RGHT, s. 138, č. 485. BIERMANN, Geschichte der Herzogthümer Troppau und Jägerndorf, s. 198, uvažoval o tom, že Mikuláš svůj dědický podíl odprodal, nebo postoupil za pravidelně vyplácenou rentu, popřípadě že krátce po rozdělení zemřel. Avšak v posledně uvedeném př́ípadě by muselo být Hlubčicko rozděleno mezi všechny zbylé bratry a nemohlo by připadnout pouze Václavovi. Navíc se Mikuláš připomíná jako žijící ještě v roce 1437, kdy mu dlužili poměrně značnou částku jeho ratibořští příbuzní. CDS VI., s. 59-61, č. 195. PRIX, Vévoda Václav II. Opavský a Hlubčický (2. část), s. 194, soudil, že Mikuláš svůj díl staršímu bratrovi „nejspíše odprodal“, avšak vzhledem k nedostatku hotovosti, s nímž se opavští Přemyslovci v této době chronicky potýkali, se ani možnost renty nejeví jako nepravděpodobná.

163 Již KOPETZKY, Zur Geschichte und Genealogie der Přemyslidischen Herzoge von Troppau, s. 52, pozn. 2, citoval nedatovaný půhon z druhé poloviny 15 . století, týkající se kylešovického zboží, v němž byl rekapitulován předchozí majetkoprávní vývoj a mělo v něm být mimo jiné uvedeno: „kněz Václav a kněz Arnošt, mladší bratřie jsúce spolu a diely svá dva spuolu držíce“. S tím, že bud' v samotné listině, nebo v Kopetzkého přepisu je zcela určitě chyba a namísto Václav má být Vilém. Možná je odrazem společné vlády obou mladších bratří i skutečnost, že při holdu slezských knížat ve Vratislavi v prosinci 1438 se jako jeho aktéři připomínají pouze Václav a Vilém, zatímco o Arnoštovi (zastoupeném Vilémem?) v této souvislosti není činěna zmínka. LBS I., s. 20-21, č. 11.

164 NA Praha, Archiv českého velkopřevorství maltského řádu, Listiny, sign. 2013. Stejnou titulaturu užil kníže také v listině z 23. dubna 1435, která je uložena v ZA Opava, Archiv města Opava, sign. VI/6, i.č. 203 a jako „Herzog und Herr zu Troppau und in Lubschütz“ vystupuje ještě v roce 1438. MINSBERG, Geschichte der Stadt Leobschütz, s. 260-264, př́loha č. 15.

165 Namátkou ZA Opava, Archiv města Opava, sign. VII/2, i.č. 14 (13. července 1436 - „,Wenczlaw, von Gotis Gnaden Herczog und Her zu Troppaw und Lupschicz“); MINSBERG, Geschichte der Stadt Leobschütz, s. 288-290, př́íloha č. 5 (24. dubna 1438 - „Wenzel, von Gottes Gnaden Herzog und Herr zu Troppau und Lubschütz“); RSW, fol. 428r-428v, č. 351 (23. ledna 1440 - „Wenzelau [sic!], von Gottes Genaden Herzog und Herre zu Troppaw und Lubschicz").

166 Starší Jan (Hanuš) se tak nazýval již v první listině vydané po otcově smrti 29. května 1446. TUREK, A. Prameny k poznání vývoje sociálních poměrů na panství hradeckém do 16. století. Slezský sborník, 1950, 52, s. 257, č. 8. Mladší Jan se poprvé připomíná v souvislosti s fundací františkánského kláštera 
stojí za zmínku, že kníže Václav přijal svůj díl Opavska v roce 1438 jako léno samostatně. To v sobě sice na jednu stranu nese informace o nezanedbatelné míre Václavovy separace ve vztahu k mladším bratrům, na druhou stranu to ale ukazuje, že Hlubčicko nemělo v rámci jeho držav žádnou zvláštní pozici. Teprve za jeho synů se zřejmě objevil náběh k oddělení obou čtvrtin, které Václav držel (tj. Hradecka a Hlubčicka), vzhledem k brzké smrti jednoho z nich se ale tento proces neměl šanci rozběhnout.

Doklady nejsou ani o existenci jakýchkoliv mocenských institucí, jejichž kompetence a reálná činnost by hlubčickému dílu přemyslovské domény dávaly punc právní, potažmo administrativní výlučnosti. V tomto směru je ovšem třeba poukázat na to, že Hlubčicko, představovalo již jen nepatrnou část Opavska v jeho původní podobě z roku 1318. Šlo vlastně jen o město s jeho blízkým okolím. Podle dílčí listiny z roku 1434 patřilo k tomuto dílu kromě Edelštejna a Cukmantlu, ztracených v roce 1440, pouze 19 vsí, z toho 2 jen zčásti. Tento počet se $\mathrm{v}$ průběhu následujících desetiletí podle všeho ještě dále ztenčil. V tomto světle je pochopitelné, že budování institucí ,zemského“ charakteru by postrádalo jakýkoliv smysl. Zbývá doplnit, že součástí Hlubčicka byl pouze jediný hrad, který mohl hrát fortifikační, respektive rezidenční úlohu, a tím byl městský hrad přímo v Hlubčicích. ${ }^{167}$ Sídlem knížat byl ovšem Hradec nad Moravicí, při pobytu v Hlubčicích využívali zřejmě také domu, jenž jim byl k dispozici prŕmo ve městě. ${ }^{168}$

Zásadní změnu poměrů přinesl odprodej Janovy části užšího Opavska, k němuž - jak bylo rozebráno výše - došlo někdy před lednem 1464. Z hlediska krále Jiřího, který se snažil vybudovat novou mocenskou základnu pro své syny, nebylo z pochopitelných důvodů žádoucí, aby jejich vládu pro futuro komplikovala postava jakéhosi konkurenčního zeměpána v osobě Jana Hlubčického. Ten ale podle všeho nebyl ochoten prodat i svou hlubčickou mocenskou základnu. Řešením, pro obě strany výhodným, bylo v tuto chvíli co nejdůslednější oddělení Opavska a Hlubčicka a respektování posledně uvedeného jako zcela samostatného knížectví. Tento nový model nenašel ovšem svůj odraz v žádném konkrétním aktu, který by mu vtiskl neoddiskutovatelný právní rámec, šlo pouze o důsledně respektované řešení politické. Nabízí se hypotéza, že právě s ním souvisel pokus o obnovu hlubčických zemských desk, jehož odrazem je opavský zápis z roku 1465. V něm Anna Bř́izková avizovala, že je připravena Mikulášovi Kečerskému „ty lány s lidmi platnými ve cky vložiti v Opavě neb v Hlubčicích, kdež to zbožie ku právu slušie“. ${ }^{169}$ Záměr ale zřejmě ztroskotal a obyvatelé Hlubčicka uživali od svého odtržení od Opavska zemských desk krnovských. ${ }^{170}$ Kromě toho, že byl Krnov o poznání blíže než Opava, tu zřejmě hrálo

v Hlubčicích - viz fundační listinu z 26. září 1448. NA Praha, Františkáni Praha, Listiny, sign. 19 (Johannes, dei gra[tia] dux Oppanie et Hlupssicz).

167 O něm blíže KOUŘIL, P. - PRIX, D. - WIHODA, M. Městské hrady v českém Slezsku. Archaeologia historica, 1997, 22, s. 256-257.

168 Tak stojí v tomto směru za pozornost např́iklad list knížete Jana z 2. července 1454, jenž byl vydán ,zu Lubschütz in Unserm Hause über dem Tische in der obersten Schwerlitz“. MINSBERG, Geschichte der Stadt Leobschütz, s. 269-273, č. 18.

169 KAPRAS (ed.), Pozůstatky knih zemského práva knížetství Opavského. Díl I. Knihy přední. Část 1. (1413-1484), s. 77, č. 123.

170 Již TILLER, Zur Geschichte der Landrechte, s. 136, konstatoval (v kontextu výkladu událostí z druhé poloviny 15. století), že hlubčičtí stavové měli právo vést řízení před krnovským soudem a klást své statky do krnovských zemských desk. KAPRAS, Oberschlesische Landbücher, s. 76; a TÝŽ, O státoprávních poměrech Opavska (2. část), s. 53, pak upozornil, že se v krnovských deskách objevují některé zápisy 
roli právě i vymezování Hlubčicka vůči Opavsku, od něhož se odpoutalo. Na tom nic nemění fakt, že kníže Jan užíval i nadále titulatury opavského knížete, která měla rodový charakter a hlásili se k ní všichni potomci Mikuláše I. v mužské linii. Podobně jako jeho krnovští př́ibuzní, i on byl posléze stále častěji počítán mezi knížata slezská. ${ }^{171}$

Teprve po Janově smrti se v roce 1487 objevuje výslovné označení ducatus Lupechyth, a to v souvislosti s obvěněním snoubenky králova syna Jana Korvína. Mezi jinými mělo jí být i na tomto knížectví cum castro et civitate Lupchiechiensi zajištěno vdovské věno. ${ }^{172}$ Zdá se ovšem, že toto označení mělo především přispět k působivosti zajištění nabízeného milánské straně. Nevelký význam hlubčického zboží, jehož centrální aglomerace byla navíc v osmdesátých letech 15 . století zpustošena požárem, se jasně projevil v jeho dalších osudech - poté, co uvedený sňatkový projekt padl, dal Matyáš vzápětí Hlubčicko do zástavy rytíri Petrovi Haugvicovi z Biskupic (†1508), který se angažoval v jeho vojenských službách. ${ }^{173}$ Ten je pak někdy na počátku 16 . století, zřejmě v roce 1503 , směnil s Janem ze Šelmberka za zástavní panství Fürstenstein ve Svídnickém knížectví. ${ }^{174}$ Vypovídací hodnota této transakce je jasná - Hlubčicko nebylo v očích svého tehdejšího držitele ničím více, než středně velkým šlechtickým panstvím.

týkající se Hlubčicka již od doby, kdy bylo Hlubčicko znovu spojeno s Opavskem v rukou vévody Přemysla I. Avšak zdá se pravděpodobné (hypotézu bude ovšem muset potvrdit hlubší analýza), že právě opětovné odtržení Hlubčicka od zbytku Opavska v polovině šedesátých let 15. století bylo rozhodujícím impulzem pro rozšíření kompetence krnovských orgánů i do této oblasti.

171 Tak se jako „Jan Opavský a Hlubčický“ objevuje v roce 1479 mezi hornoslezskými knížaty, která se přiznala k olomouckému míru a přijala za svého pána krále Matyáše (dalším ze signatářu byl i „Hanuš starší Opavský a Ratiborský“, vládnoucí ale v té době již jen vladislavským panstvím). AČ V., s. 387-389, č. 14. Jako „Herczog in Slesien von Troppaw zu Lubschicz“ je Jan zmíněn také v listině vratislavského biskupa Rudolfa z 12. listopadu 1481. RSW, fol. 362r-364v, č. 290; CDS VI., s. 111, č. 335. Právě tato intitulace perfektně zachycuje jeho stávající pozici.

172 LBS I., s. 33, č. 19.

173 Poznání dějin Hlubčic a Hlubčicka na přelomu 15. a 16. století je česká historiografie dodnes mnoho dlužna. Z regionálních děl je tato perioda zřejmě nejpřínosněji zpracována v TROSKA, F. Geschichte der Stadt Leobschütz. Leobschütz: Druck und Verlag von W. Witke, 1892, s. 45-53 - autor zde vyšel z pozdějších akt ze třicátých let 16. století, jimž ale nelze upřít značnou míru věrohodnosti. Víceméně z něj vychází i nejnovější práce MALER, K. Dzieje Gtubczyc do 1742 r. jako przyktad rozwoju górnośląskiego ośrodka miejskiego w epoce przedindustrialnej. Opole: Wydawn. Instytut Śląski, 2003. Podle Trosky (s. 46) došlo k zástavě Hlubčic krátce před Matyášovou smrtí, v letech 1489-1490. Naproti tomu PRIX, D. Středověký městský kostel Panny Marie v Hlubčicích. Průzkumy památek, 2003, 2/X, s. 11, pozn. 49, upozornil, že držba Petra Haugvice je doložena již roku 1488, přičemž zástavní suma byla relativně velmi nízká s ohledem na nedávný požár, který město zachvátil.

174 TROSKA, Geschichte der Stadt Leobschütz, s. 48; k majetkové expanzi Šelmberků v oblasti Slezska stručně též MAŤA, P. Svět české aristokracie (1500-1700). Praha: NLN - Nakladatelství Lidové noviny, 2004, s. 138, podle něhož ale Šelmberkové uvedenou směnu realizovali s králem Vladislavem. Což zřejmě neodpovídá skutečnosti již z toho pohledu, že Haugvicům patřilo fürstensteinské panství až do roku 1509, kdy ho koupili Hochbergové. Nedostatečné poznání právních vztahů k Hlubčicím dokumentuje také královská listina z 20. února 1511, podle níž Hlubčicko dostal Jan ze Šelmberka nejprve jako dědičné vlastnictví, ,z hodných a znamenitých příčin“, ale následně panovníkovi vrátil příslušný list a Hlubčicko podržel jen jako zástavu v částce 14000 uherských zlatých a 362 a 1⁄2 kopy pražských grošů. Po Janově smrti mělo na žádost jeho syna Jiřího dojít k opětovnému převedení země do dědičné držby, ,poněvadž jsou již ty příčiny minuly a přešly, pro kteréž Nám nahoře psaný Jan týž list na dědictví zase navrátil“". Opis dokumentu je v StA Nürnberg, fond Fürstentum Brandenburg-Ansbach, Herrschaftliche Bücher, Nr. 29, fol. 85r-87v; na základě jiného, v Berlíně uchovávaného kopiáře byl zpracován obsáhlý regest v LBS II., s. 541, č. 90 . 
Pro Šelmberky, kteří ve snažili v Horním Slezsku vybudovat kompaktní základnu své rodové moci, měl ovšem potenciálně vyšší status Hlubčicka svoji hodnotu. Svědčí o tom intitulace Jiřího ze Šelmberka v listině z 22. února 1506, jíž společně se svou tchýní postoupili svá sporná práva na Landek, Hlučín a Křenovice ratibořským knížatům: Barbora se tu spokojila s obvyklým ,z Buoží mi[los]ti kněžna opavská a ratibořská a paní krnovská““, avšak ani Šelmberk se nenechal zahanbit a označil se jako „pán kniežetství krnovského a hlubčicského“. ${ }^{175}$ Uvedená titulatura přitom znamenitě souzní s výše uvedenou dohodou z roku 1497, podle níž připadlo Barboře především město Krnov, zatímco většina země měla být předána Šelmberkům; k Hlubčicku bylo jejich právo nesporné.

Na počátku 16. století došlo tedy ke sjednocení vlády v obou teritoriích odtržených od někdejšího „,velkého“ Opavska; teritoriích, která se beztak již předtím právně sbližovala díky zapisování hlubčických statků do krnovských zemských desk. Nic na tom nezměnila ani skutečnost, že zanedlouho, v roce 1509 dal Jiří ze Šelmberka Hlubčice s př́íslušenstvím do zástavy Janu Planknarovi z Kynšperka v částce 8000 zlatých. ${ }^{176}$ Tím byla sice Hlubčicku dána určitá autonomie, nic to ale neměnilo na jeho podřizení svrchovanosti krnovských pánů. Hlubčice jsou také pochopitelně jmenovány jako součást majetku, který Jiř́ ze Šelmberka se svými syny v roce 1523 prodal braniborsko-ansbašskému markraběti Jiřímu. ${ }^{177} \mathrm{~V}$ rukou zástavních držitelů zůstaly do roku 1532, kdy je na Velikonoce převzali plnomocníci nového krnovského knížete. ${ }^{178}$ Od té doby již není po svébytném Hlubčicku památky, město a jeho okolí byly brány jako integrální součást Krnovska a ani formální označení hlubčického vévody se nestalo součástí titulatury krnovských Hohenzollernů. ${ }^{179}$

V rámci závěrečné rekapitulace je tedy možno konstatovat, že i když lze ve vývoji Krnovska a Hlubčicka nalézt mnohé paralely, z hlediska státoprávního vedl k poněkud odlišným koncům. Ne ovšem v první fázi tohoto vývoje, kdy dělení mezi přemyslovské bratry v roce 1377 znamenalo vytvoření tří separovaných územně-správních celků, které byly sice všechny chápány jako rovnocenné deriváty Opavského vévodství, ve skutečnosti ale bylo jejich pouto založeno pouze na (leckdy problematické) rodové solidaritě. Jednotliví bratři obdrželi svá území od českých Lucemburků jako léno samostatně, a dokonce ani vzájemný dědický nápad nebyl samozřjejmostí - v lenní listině z roku 1378 na opavskou část země byl stanoven pro mladší syny z třetího manželství Mikuláše II., Václava a Přemysla, s pominutím ostatních mužských sourozenců, a po smrti Mikuláše III. dědil

175 RSW, fol. 101v-102r, č. 65; regesty jsou v CDS VI., s. 154-155, č. 462, a LBS II., s. 533, č. 78. Toho, že Šelmberkové v roce 1506 hovoří o „,ihrem Fürstenthume Lubschütz“ si povšiml také TILLER, Zur Geschichte der Landrechte, s. 136.

176 TROSKA, Geschichte der Stadt Leobschütz, s. 50; PRIX, Středověký městský kostel Panny Marie v Hlubčicích, s. 11.

177 LBS II., s. 547-549, č. 97.

178 PRIX, Středověký městský kostel Panny Marie v Hlubčicích, s. 11.

179 Namátkou listina Jiř́iho pro opavské klarisky z 4. července 1526 („Marggraf zu Brandemburg, in Slesien, Preussen, zu Ratibor, Jegerdorf, Stetin, Pomern, der Cassuben unnd Wenden Hertzog, Burggraf zu Nurmberg unnd Furst zu Rugen“) a potvrzení privilegií krnovských stavů z 3. ledna 1528 („Marggraue zue Brandenburgk, in Schlesien zue Jegerdorff, Ratbor, zue Schtettin, Pommern, der Casschuben und Wenden Herzcog, Burggraue zu Nurenbergk und Fuerst zue Rugen“) či listina jeho syna Jiř́ího Bedřicha o obnovení krnovského zemského práva v roce 1573 („Marggraf zu Brandenburgk, zu Stettin, Pommern, der Cassubenn und Wenden, auch in Schlesien zu Jegerndorf und etc. Hertzogk, Burggraf zu Nurmbergk unnd Furst zu Rugenn“). ZA Opava, fond Klarisky Opava, i.č. 42, sign. A 15; SSAO, sign. B I-2, i.č. 482, sign. B I-36, i.č. 542 . 
jeho hlubčický díl pouze Přemysl, nikoliv příslušníci ratibořské primogenitury. Neprodleně po dělbě se také konstituovaly vlastní zemské orgány jednotlivých částí. Hovořit o Krnovském, resp. Hlubčickém knížectví by sice v této době bylo anachronismem, prakticky lze ale na situaci nahlížet tak, že se pod pojmem Opavské vévodství skrývaly tři samostatné státoprávní entity.

Rozhodujícím předpokladem pro odlišnost dalších osudů Krnovska a Hlubčicka se bez jakékoliv pochybnosti stala devadesátá léta 14. století. Zatímco Krnovsko se dostalo do dlouhodobé zástavní držby moravského markraběte Jošta a byt' personálně spojeno s Moravou, dále rozvíjelo svoji svébytnost (byly zde zachovány zemský soud i zemské úřady a došlo navíc i k významné reorganizaci zemských desk), Hlubčicko bylo spojeno s opavským dílem vévody Přemysla, který naopak systematicky podnikal kroky k tomu, aby byla obě území pokud možno integrována (mimo jiné právě zrušením zdejších orgánů i desk). Zajímavý pokus o posílení rodové soudržnosti prostřednictvím opětovného uznání vzájemné dědičnosti se odehrál na počátku 15. století, a to jednak prostřednictvím královské listiny, která v roce 1404 prohlásila všechny přemyslovské državy za společné léno (ovšem bez toho, že by omezila výlučnou vládu jednotlivých linií nad jejich knížectvími), jednak následnou dědickou dohodou z roku 1407. Avšak od této dohody obě strany během relativně krátké doby odstoupily a navíc, její platnost se v relevantním časovém úseku nevztahovala na Krnovsko, které mělo jiného vlastníka.

Teprve s odezníváním husitských válek se v obou liniích přemyslovské dynastie odehrálo opětovné dělení rodových držav. V roce 1434 se rozdělili čtyři synové Přemysla I. Opavského, o tři roky později je následovali dva synové Jana II. Ratibořského. I když mají obě česky psané dílčí listiny obdobný charakter, už s ohledem na počty účastníků vedla tato ujednání k rozdílným výsledkům. Zatímco ve druhém z uvedených př́ípadů došlo k dosti hlubokému řezu a vznikly dva územní celky, jejichž samostatnost podporovala existence vlastních zemských úřadů v Ratiboři i v mezitím (roku 1422) nazpět získaném Krnově, u Opavska se čtyři soběstačné díly daly vytvořit jen stěží. Ostatně se zdá, že jistá míra společné vlády (determinovaná již existencí jednotného zemského práva a institucí) byla v intencích vývoje a v souladu s nabádáním k bratrské soudržnosti, zakotveným v Přemyslově závěti z roku 1433. Během krátké doby sice došlo k částečnému překonání územněsprávního rozdrobení, když Václav II. spojil ve svých rukou dva ze čtyř dílů a zbylé dva spravovali ve vzájemné shodě Vilém I. a Arnošt I., ani to ale podle všeho nevedlo k odcizování těchto částí. Mimo jiné zřejmě i proto že Václavův díl nebyl teritoriálně souvislý (kromě dílu města Opavy k němu patřilo jižně od ní položené panství Hradec, a naopak výrazně severněji situované Hlubčicko).

Existovalo tedy v 15. století knížectví krnovské, resp. hlubčické? Zatímco v období raně novověkém se již lze v panovnické kanceláři setkat s poměrně vyspělým státoprávním uvažováním a odpovědi na podobné otázky není těžké nalézt v textu pragmatických písemností, středověké prameny jsou v tomto ohledu mnohem méně vstrrícné. Státoprávní situaci je tak třeba pokoušet se pojmenovat na základě nepřímých a v mnoha př́ípadech také nejednoznačných důkazů. O Krnovsku tak lze prohlásit, že podle všech relevantních ukazatelů bylo od roku 1437 opět samostatným lenním knížectvím, i když název Krnovské vévodství se prosazoval pomalu. Zpočátku mimo jiné i díky spojení s rybnickým panstvím, odděleným od historického Ratibořska, kdy právě rybnický hrad plnil ve vztahu k Mikulášovi VI. rezidenční funkci. Po dalším dělení v roce 1465 se državy ratibořské 
primogenitury rozpadly na tři samostatné státoprávní celky - Krnovsko (k němuž zůstávalo připojeno původně ratibořské panství Vladislav), Rybnicko a samotné Ratibořsko. Státoprávní svébytnost Krnovska jako lenního knížectví České koruny, počítaného mezi knížectví hornoslezská, pak trvala až do poloviny 19. století, i když s poněkud pozměněným obsahem od rozdělení Slezska v roce 1742.

Pokud jde o Hlubčicko, zde lze zřejmě za svým způsobem zlomový považovat moment (jehož přesná datace není známa, snad k tomu došlo v roce 1463), kdy Jan IV. Opavský prodal králi Jiřímu z Poděbrad a jeho synům panství Hradec a díl města Opavy a ponechal si právě jen hlubčické teritorium. Jak pro Poděbrady, kteří z pochopitelných důvodů neprahli po narušení své suverenity, tak pro samotného knížete Jana nebylo perspektivní považovat nadále Hlubčicko za součást Opavska, ale mnohem praktičtější bylo nahlížet na něj jako na svébytný státoprávní celek. Vzhledem k tomu, že šlo o území geograficky velmi omezené, nevytvořila se tu již vlastní zemská správa. Dosti zajímavá je ale hypotéza, že právě v souvislosti s ,vyšachováním“ knížete Jana z opavských záležitostí začaly být hlubčické statky ve větší míře zapisovány nikoli do opavských, nýbrž do krnovských zemských desk. Bezdětnou smrtí předposledního příslušníka opavské přemyslovské sekundogenitury (posledním zůstal jeho bratranec Přemysl III., farář v Mödlingu u Vídně, který zemřel o deset let později ${ }^{180}$ ) ztratila další existence Hlubčického vévodství své politické opodstatnění. Z pragmatických důvodů ho uvedl ještě král Matyáš v roce 1487 (po boku Krnovského vévodství) v listině o budoucím zajištění snoubenky svého jediného potomka, stejně tak se k němu přihlásili ještě Šelmberkové v roce 1506. Fakticky bylo ale Hlubčicko v 16. století zcela integrováno do Krnovského vévodství a jeho samostatná existence tak tak zůstala omezena na dobu jen o málo přsahujíc dvě desetiletí. ${ }^{181}$

Nelze samozřejmě na závěr nezdůraznit, že juristicky laděná analýza vrcholně a pozdně středověkých poměrů může poučenému čtenáři zavánět anachronismem a do jisté míry se zaobírá problémy, jejichž naléhavost současníci mnohdy zřejmě nijak výrazně nepocitovali. Na druhou stranu se ale zdá nepochybné, že právní historie s ohledem na své zaměření nemůže rezignovat na snahu o precizní a systematické popsání právních poměrů v minulých epochách, přičemž zpětná projekce současných paradigmat a terminologie nemusí nutně znamenat metodický lapsus, je-li užívána v kontextu dobového vnímání a uvažování. Každopádně se sluší zdůraznit, že středověké a raně novověké dějiny Opavska a Krnovska a vedlejších zemí Koruny české vůbec patří k málo akcentovaným předmětům zájmu české historiografie a že pro další právněhistorický výzkum se tu otevírají široké prostory. $\mathrm{Z}$ tohoto pohledu je třeba předkládanou studii chápat pouze jako jakousi jeho dílčí prolegomenu.

180 O něm naposledy bliže MĚŘÍNSKÝ, Z. Marginálie k životním osudům Přemysla III. Opavského. In: DOLEŽALOVÁ, E. - ŠIMŮNEK, R. (eds.). Od knižat ke králi̊m. Sborník u př́ležitosti 60. narozenin Josefa Žemličky. Praha: Nakladatelství Lidové noviny, 2007, s. 423-437.

181 Nelze tedy souhlasit s tím, že Hlubčicko „,bildete ... 1365-94 und 1434-82 ein eigenes Fürstentum“, jak tvrdil WECZERKA, Handbuch der historischen Stätten, s. 276. 